\title{
Hypertension and target organ damage
}

\author{
Citation for published version (APA):
}

Rodriguez Hernandez, S. A. (2002). Hypertension and target organ damage. [Doctoral Thesis, Maastricht University]. Universiteit Maastricht. https://doi.org/10.26481/dis.20021218sr

Document status and date:

Published: 01/01/2002

DOI:

10.26481/dis.20021218sr

Document Version:

Publisher's PDF, also known as Version of record

\section{Please check the document version of this publication:}

- A submitted manuscript is the version of the article upon submission and before peer-review. There can be important differences between the submitted version and the official published version of record.

People interested in the research are advised to contact the author for the final version of the publication, or visit the DOI to the publisher's website.

- The final author version and the galley proof are versions of the publication after peer review.

- The final published version features the final layout of the paper including the volume, issue and page numbers.

Link to publication

\footnotetext{
General rights rights.

- You may freely distribute the URL identifying the publication in the public portal. please follow below link for the End User Agreement:

www.umlib.nl/taverne-license

Take down policy

If you believe that this document breaches copyright please contact us at:

repository@maastrichtuniversity.nl

providing details and we will investigate your claim.
}

Copyright and moral rights for the publications made accessible in the public portal are retained by the authors and/or other copyright owners and it is a condition of accessing publications that users recognise and abide by the legal requirements associated with these

- Users may download and print one copy of any publication from the public portal for the purpose of private study or research.

- You may not further distribute the material or use it for any profit-making activity or commercial gain

If the publication is distributed under the terms of Article $25 \mathrm{fa}$ of the Dutch Copyright Act, indicated by the "Taverne" license above, 


\section{Hypertension and target organ damage}

Rodríguez Hernández SA 
The publication of this thesis was financially supported by: AstraZeneca, Bayer BV, Boehringer Ingelheim, Bristol-Myers Squibb BV, Menarini Farma Nederland, Merck Sharp \& Dohme BV, Novartis Pharma BV, Pfizer BV, Servier Nederland BV, Yamanouchi Pharma BV.

Hypertension and target organ damage.

S.A. Rodriguez Hernández

Thesis Universiteit Maastricht

ISBN 90-9016404-9

c) 2002, S.A. Rodriguez Hernández, Maastricht The Netherlands

All rights reserved, whether the whole or part of the material is concerned. No part of this publication may be reproduced, stored in a retrieval system, or transmitted in any form or by any means, electronic, mechanical, photocopying, recording or otherwise, without written permission from the copyright owner. 


\section{Hypertension and target organ damage}

\section{PROEFSCHRIFT}

ter verkrijging van de graad van doctor aan de Universiteit Maastricht,

op gezag van Prof. dr. A.C. Nieuwenhuiizen Kruseman,

Rector Magnificus,

volgens het besluit van het College van Decanen, in het openbaar te verdedigen

op woensdag 18 december 2002 om 16.00 uur

door

Sergio Alejandro Rodríguez Hernández

Geboren op 19 maart 1971 te Bogotá, Colombia 


\section{Promotor}

Prof. dr. P.W. de Leeuw

Co-promotores

Dr. A.A. Kroon

Dr. M.P.J. van Boxtel

Beoordelingscommissie

Prof. dr. H.F.P. Hillen (voorzitter)

Dr. E.C. Cheriex

Prof. dr. D.L. Clement (University Hospital Gent, België)

Prof. dr. Th. Thien (Katholieke Universiteit Nijmegen)

Prof. dr. J. Troost

This thesis was prepared at the Department of Internal Medicine, University Hospital Maastricht, The Netherlands 


\section{Contents}

Chapter 1 Introduction

Chapter 2 Is elevation of clinic blood pressure in patients with white coat hypertension who have normal ambulatory blood pressure associated with target organ changes?

Chapter 3 Left ventricular hypertrophy and renal impairment are associated with reduced nocturnal blood pressure decline, even in adequately treated hypertensives

Chapter 4 Blood pressure profile and its relation to cerebral white matter lesions in untreated hypertensives

Chapter 5 Is there a side predilection for cerebrovascular disease?

Chapter 6 Effect of polymorphisms of the angiotensin-converting enzyme and apolipoprotein E on carotid intima-media thickness in untreated hypertensives

Chapter 7 General discussion

Chapter 8 Summary

Chapter 9 Samenvatting

Dankwoord

Curriculum vitae 

Chapter 1

Introduction 
$10 \mid$ Chapter 1 


\section{Introduction}

Cardiovascular disease, and hypertension in particular, is an important cause of morbidity and mortality in the general population. Whereas major efforts have been undertaken to prove the benefits of antihypertensive treatment, our understanding of the pathophysiological processes that are associated with the pathogenesis of the disorder remains limited. When left untreated, hypertension may cause considerable damage to the cardiovascular system, leading to such complications as myocardial infarction, cerebrovascular accident, peripheral vascular disease and renal failure. More recently, other complications (e.g. open-angle glaucoma, retinal vascular occlusion) have been recognized as being linked to hypertension as well.

Before major complications occur, subclinical target organ damage (TOD) develops. This may include left ventricular hypertrophy, an increased intimamedia thickness of larger vessels, glomerular obliteration and an increased intra-ocular pressure. For years, these events have been neglected and even today many physicians fail to seek properly for TOD in their patients. Yet, epidemiological studies have clearly shown that the presence of TOD enhances cardiovascular risk over and above that already associated with the elevated pressure. For instance, once left ventricular hypertrophy has developed as a result of long-standing hypertension, this complication becomes a risk factor in its own right and a predictor not only of further cardiac abnormalities', but also of other atherothrombotic events such as ischemic stroke. ${ }^{2}$ Similarly, the presence of cerebrovascular abnormalities may raise cardiovascular risk over and above that conferred by hypertension itself. Although the brain and the heart are the prime targets of the hypertensive process, the kidney is also frequently affected. Evidence is accumulating that renal damage, once present, may also independently contribute to an increased cardiovascular risk. ${ }^{3,4}$ This knowledge calls for a more elaborate work-up of hypertensive patients in order to identify those subjects who are particularly at risk.

Although not proven, it is generally assumed that target organ damage develops as a consequence of an elevated pressure and that it precedes the clinical manifestations of cardiovascular disease. In other words, TOD can be considered as an intermediate endpoint of the hypertensive process and, as such, could even serve as a substitute for morbidity and mortality in large-scale clinical trials. If this is true, it is important to know which components of blood pressure are most closely linked to TOD as it is well known that blood pressure is not a static phenomenon but varies greatly throughout the day. Although one measurement of blood pressure, taken at the office, already correlates reasonably well with cardiovascular damage and prognosis, substitution of casual pressure by 'usual blood pressure', defined as the average of multiple measurements on various occasions, improves the relationship considerably. While it may be true that obtaining many blood pressure readings at the office is 
more or less equivalent to 24-hour ambulatory measurements for assessing a patient's usual blood pressure and cardiovascular risk ${ }^{6}$, the latter technique is much more practical and yields results within one day. Indeed, under a variety of conditions ambulatory blood pressure monitoring (ABPM) has proven to be superior to conventional blood pressure measurements not only for the diagnosis of hypertension but also for establishing its severity. Non-invasive ambulatory blood pressure measurements even appear to be a better predictor of outcome than clinic blood pressure. The development of rather cheap, validated devices which can be easily worn by the patient make ABPM an interesting tool to employ in clinical practice.

Blood pressure varies markedly over a 24-hour period. Some fluctuations are due to acute events, either physical or psychological. In addition, there is a circadian pattern: blood pressure is highest in the morning, falls slightly during the day and rises to a second peak in the late afternoon. It then falls again during the evening. When an individual goes to sleep, blood pressure falls markedly and stays at relatively low levels during the sleeping period. On awakening there is an acute rise in blood pressure, which has been refered to as the early morning peak. Data suggest that morbidity and mortality from cardiovascular and cerebrovascular disease is greatest in the hours around the awakening, neriod. There are three fynes of information that ABPM can, norovide First, it can give an estimate of the average or true blood pressure, which is the measure generally thought to be responsible for most of the adverse effects of high blood pressure. Secondly, it can describe the diurnal rhythm. Thirdly, it can give an estimate of the short-term variability of blood pressure.

Despite many investigations, the prognostic impact of 24-hour blood pressure variability has not yet been fully explored. It is easy to identify, in 24-hour blood pressure recordings, the presence or absence of a large nocturnal decline in pressure. Also, several studies have assessed the relationship between 24-hour averages of pressure and TOD or prognosis. However, it is only recently that the importance of nighttime blood pressure has been appreciated. For instance, the investigators from the Syst-Eur study have clearly shown that the best predictor of future cardiovascular complications in an elderly population with isolated systolic hypertension is nighttime pressure. ${ }^{7}$ Others have pointed out that the magnitude of the nocturnal dipping of blood pressure is associated with, for instance, left ventricular hypertrophy. ${ }^{8}$ So it is far from clear as to whether the precent dipping or the actual night time blood pressure are involved in cardiovascular load. These considerations have led us to start a series of investigations in which we have tried to explore the significance of the diurnal blood pressure profile in more detail. The results of this endeavour form the core of this thesis.

In Chapter 2 of this thesis the question is addressed whether patients with white coat hypertension have target organ changes. Although there are various ways to define white coat hypertension, it is usually considered as a condition in which the patient has elevated blood pressure in the office, but on average, has a normal pressure during 24-hour ambulatory monitoring. Whether or not this is a benign form of hypertension with a favourable course and low risk of complications is still a matter of dispute. While some argue that white coat 
hypertension carries a relatively low risk compared to sustained hypertension?, others take a more dim view based on the fact that white coat hypertension has characteristics similar to borderline hypertension and is associated with several metabolic risk factors. ${ }^{10}$ To date, no outcome studies have been performed that were specifically designed to assess the effect of antihypertensive treatment on complication rates in patients with white coat hypertension. By establishing the degree of target organ damage in a group of patients with this condition, we wanted to provide additional evidence for or against the opinion that the white coat effect is a benign phenomenon.

Chapter 3 examines the relationship between 24-hour blood pressure and cardiorenal damage. In particular, the various components of the diurnal blood pressure profile (daytime pressure, nighttime pressure and the amount of nocturnal dipping) are related to left ventricular mass and renal function (serum creatinine and creatinine clearance). Since it is not well known whether the heart and the kidney respond differently to the burden of an elevated blood pressure burden, we performed additional analyses to evaluate if the relationship between blood pressure and degree of organ damage runs different courses for these two targets. Moreover, analyses were done in untreated and treated subjects, which allowed conclusions to be drawn about the potential modification of the pressure-damage relationship by antihypertensive treatment. Chapter 4 focuses on the subclinical cerebral white matter leasions (WML) in hypertension. To this end, we measured white matter lesions and cognitive functions in a group of hypertensive subjects. In this study we wanted to determine which components of ambulatory blood pressure profile are best associated with the presence of WML in hypertensives. Chapter 5 continues on this topic but now looking at the common carotid intima-media thickness (IMT) as intermediate form of damage, as an increase in this measure is considered to represent a phase of the atherosclerotic process that precedes overt complications. This chapter also looks at the possibility that left-right differences may exist in IMT and in the occurrence of atherosclerotic cerebrovascular lesions. In Chapter 6 the changes in IMT are related to two candidate genes for atherosclerotic lesions: the ACE-gene and the gene encoding apolipoprotein E. Finally, in Chapter 7 the results of the various studies are summarized and put in perspective. 


\section{References}

1. Levy D, Garrison R, Savage DD, Kannel WB, Castelli WP. Prognostic implications of echocardiographically, determined left ventricular mass in the Framingham Heart Study. N Engl J Med 1990;322:1561-1566.

2. Bikkina M, Levy D, Evans JC, Larson MG, Benjamin EJ, Wolf PA, et al. Left ventricular mass and risk of stroke in an elderly cohort. The Framingham Heart Study. JAMA 1994;272:33-36.

3. Ruilope LM, Salvetti A, Jamerson K, Hansson L, Warnold I, Wedel H, et al. Renal function and intensive lowering of blood pressure in hypertensive participants of the Hypertension Optimal Treatment (HOT) study. I Am Soc Nephrol 2001;12: 218-225.

4. De Leeuw PW, Thijs L, Birkenhager WH, Voyaki SM, Efstratopoulos AD, Fagard RH, et al. Prognostic significance of renal function in elderly patients with isolated systolic hypertension: results from the syst-eur trial, J Am Soc Nephrol 2002;13: 2213-2222.

5. MacMahon S, Peto R, Cutler J, Collins R, Sorlie P, Neaton J, et al. Blood pressure, stroke, and coronary heart disease. Part 1, Prolonged differences in blood pressure: prospective observational studies corrected for the regression dilution bias. Lancet 1990;335:765-774.

6. Fagard RH, Staessen JA, Thiis L. Prediction of cardiac structure and function by repeated clinic and ambulatory blood pressure. Hypertension 1997;29:22-29.

7. Stoessen JA, Thijs L, Fagard R, O'Brien ET, Clement D, De Leeuw PW, et al. Predicting cardiovascular risk using conventional vs ambulatory blood pressure in older patients with systolic hypertension. Systolic Hypertension in Europe Trial Investigators. JAMA 1999;282:539-546.

8. Verdecchia P, Schillaci G, Guerrieri M, Gatteschi C, Benemio G, Boldrini F, et al. Circadian blood pressure changes and left ventricular hypertrophy in essential hypertension. Circulation 1990;81:528-536.

9. Fagard RH, Staessen JA, Thiis L, Gasowski J, Bulpitt CJ, Clement D, et al. Response to antihypertensive therapy in older patients with sustained and nonsustained systolic hypertension. Systolic Hypertension in Europe (Syst-Eur) Trial Investigators. Circulation 2000;102:1139-1144.

10. Julius S, Mejia A, Jones K, Krause L, Schork N, van de Ven C, et al. "White coat" versus "sustained" borderline hypertension in Tecumseh, Michigan [see comments]. Hypertension 1990;16:617-623. 


\section{Chapter 2}

Is elevation of clinic blood pressure in patients with white coat hypertension who have normal ambulatory blood pressure associated with target organ changes? 


\section{Abstract}

\section{Background}

The issue as to whether white coat hypertension is a pathologically significant entity, with associated target organ changes, or that the condition carries the same risk for target organ involvement as normotension, is undecided. Previous studies which have shown pathological correlates between white coat hypertension and target organ damage have not controlled for the most obvious confounder, mean 24 hour blood pressure (BP).

\section{Methods and results}

In this study we retrospectively identified 33 ages and sex-matched pairs, one group with normal BP, the other with white coat hypertension. The white coot hypertensive group showed significantly greater left ventricular mass indexed for body surface area than normal controls $\left(99.0 \mathrm{~g} / \mathrm{m}^{2}\right.$ vs. $\left.78.3 \mathrm{~g} / \mathrm{m}^{2}, \mathrm{p}<0.001\right)$. The population was then further matched for 24-hour mean BP (20 pairs), and was again compared for cardiac muscle changes. The significantly increased left ventricular mass index in the white coat population remained after controlling for 24 -hour mean BP $\left(101.1 \mathrm{~g} / \mathrm{m}^{2} \mathrm{vs} .81 .0 \mathrm{~g} / \mathrm{m}^{2}\right.$, $p<0.021$ ).

\section{Conclusion}

White coat hypertension is indeed associated with a larger left ventricular muscle mass than normotensives and these changes are independent of the actual 24-hour BP load, and may reflect increased BP lability, sympathetic nervous system derangement, or a genetic propensity in people with white coat hypertension to stress-related hypertensive reactions, as part of a pre-hypertensive state. 


\section{Introduction}

White coat hypertension has long been recognised as an acute elevation of blood pressure (BP) occurring in the context of active third party BP measurement.' Variously termed 'white coat hypertension', 'clinical hypertension', or 'isolated clinic hypertension'2 (we will herein refer to the phenomenon as white coat hypertension (WCH)), it has been assumed that the lack of sustained hypertension in these patients reflects a reactive sympathetic nervous system, and predicts a benign prognosis. A number of studies looking at evidence of target organ damage have given equivocal results; left ventricular hypertrophy and renal dysfunction have both been described as occurring in association with $\mathrm{WCH}^{3-8}$, while other studies have not documented an association..$^{9-12}$ These studies have largely shown significantly higher mean $\mathrm{BP}$ in the WCH group, and it may be that the documented elevation of cardiac and renal indices of end-organ involvement found in these studies are simply a reflection of this higher $\mathrm{BP}$ in this group. ${ }^{13}$

In this case-control study, we identified a large cohort of patients with WCH defined on 24-hour ambulatory BP (ABP) monitoring, and an age and sexmatched normal cohort drawn from the normal population. Groups were compared for $\mathrm{ABP}$ profiles, and the presence of target organ involvement, namely the presence of myocardial hypertrophy. The groups were then further matched for 24-hour mean arterial BP, and the comparison for left ventricular mass index (LVMI) was then repeated, to determine if controlling for BP differences between the populations would remove the perceived differences in target organ involvement.

\section{Subjects and Methods}

\section{Patient population}

Patients were identified from a search of the database in the Blood Pressure Unit (Beaumont Hospital, Dublin, Ireland), which comprises patients referred to the hospital for investigation of hypertension. Patients referred to this service routinely have electrocardiography and echocardiography performed within 1 week of the ABP monitor being applied. Patients were selected if they met with the following definition of $\mathrm{WCH}$, namely an elevation of the clinic $\mathrm{BP}$, with or without an elevation of the initial BP (first hour) on the ABP monitor above 140 $\mathrm{mmHg}$ systolic and/or $90 \mathrm{mmHg}$ diastolic, with a normalisation of the BP to below these figures within the next hour, and a subsequently normal $\mathrm{BP}$ mean for both daytime (systolic $135 \mathrm{mmHg}$, diastolic $85 \mathrm{mmHg}$ ) and night-time (systolic $125 \mathrm{mmHg}$, diastolic $70 \mathrm{mmHg}$ ) monitoring periods. Patients were excluded if the above definition was not met, or if the routine screening tests 
were not performed. Also, patients were not included if they were documented as taking antihypertensive medication at any time prior to referral for the ABP monitor. Shift workers were excluded from the analysis.

\section{Control population}

Control patients were enrolled from a database of $A B P$ in the normal population, the initial study of which has been described elsewhere. ${ }^{14}$ Patients from this population have been routinely brought back for follow-up study, from 1995 onward, and had electrocardiography and echocardiography performed on the day of the ABP monitor. A total of 130 control subjects were available for cross matching. WCH patients were assigned age and sex-matched controls from this database. The matching procedure was undertaken without knowledge of the patients BP variables, by a physician told only: (1) which patient cohort the subject belonged to; and (2) age and sex. Only controls with a normal clinic, initial, daytime and nighttime ABP profile according to the above definition were enrolled. Again, patients were excluded if the screening data was deficient, or if they were taking medicines known to interfere with BP.

\section{Echocardiography}

Echocardiography was performed by a trained echo-cardiographer using a standard $2.5 \mathrm{MHz}$ echocardiography transducer applied to the chest in the parasternal long and short axis planes, where measurements of wall thickness, and chamber size were made. To ensure there was no systematic observer bias, three $M$-mode tracings were printed from each of the videotaped studies; a trained technician then manually measured the chamber parameters, blinded to the case-control status of the patients, and took the mean dimensions for the three tracings as the measured variable. The left ventricular mass was calculated from these parameters using the formula of Devereux et al. ${ }^{15}$ This was subsequently indexed for body surface area.

\section{Blood pressure measurement}

Clinic BP was measured in accordance with the recommendations of the British Hypertension Society. ${ }^{16}$ For controls, all readings were required to be below 140 $\mathrm{mmHg}$ systolic and $90 \mathrm{mmHg}$ diastolic. All case patients had an elevated clinic $\mathrm{BP}$ on referral from their general practitioner, and all had an elevated clinic BP again when measured in the Blood Pressure Unit prior to the affixing of the ABP monitor. The clinic pressures were measured in both cases and controls (affer 5 min quiet sitting) by the Unit nurse, prior to affixing the ABP monitor. The lower reading was taken as the clinic pressure, and this value was entered into the database. Twenty-four ABP measurement was performed using the Spacelabs 90207 (Redmond, WA, USA) ABP monitor. ${ }^{17}$ Monitors were programmed to measure $B P$ at $30-\mathrm{min}$ intervals day and night. The monitor was removed the next day, and the data was transferred into a personal computer and loaded into a specialised software package (DABL). ${ }^{18}$ The initial, daytime and night-time 
systolic, diastolic and mean BP were calculated. The 'daytime' period was defined as the hours between 09.00 and 21.00 hours (excluding the initial period), and night-time as the hours between 01.00 and 06.00 hours. The 24-h period was defined as the total period of measurement time from application to removal of the monitor. Transition times $(21.01$ to 00.59 hours, and 06.01 to 08.59 hours) were not included in the estimation of day and night mean pressures, as these periods represent times during which bed rest is inconsistent and therefore cannot reliably be categorised. ${ }^{19}$ Patients on night shift work, or within 4 weeks of completing night shift duty, were not included in the analysis. Recordings were not included if there were less than 14 valid readings during the day, or less than seven valid readings during the night. The validity criteria were those identified by the editing software, i.e., systolic BP, diastolic BP, diastolic BP $<160$ or $>40 \mathrm{mmHg}$, systolic $\mathrm{BP}<260$ or $>50 \mathrm{mmHg}$. BP values not identified by the editing software were included in the analysis. ${ }^{20}$

\section{Definitions and statistics}

Clinical data was extracted from the database, in accordance with the following definitions. Family history of hypertension was defined as the reporting of hypertension in a first degree relative. A family history of vascular disease was present if one or more first-degree relatives had suffered a myocardial infarction, angina pectoris, a cerebrovascular accident or had been given a diagnosis of peripheral vascular disease. The presence of any other medical condition identified from the clinical review at time of monitoring was considered a potential confounder and this patients record was not included in the analysis. The initial matched groups were compared for BP variables, and for left ventricular mass; the pairs were then further matched for BP by assigning a sexspecific sequential ranking code to the mean 24-hour BP for subjects in each group. The ranked pairs obtained were then compared for actual BP and age; corresponding BP values and age not differing by $2.5 \mathrm{mmHg}$ and 2 years were deemed acceptably paired and this pairing was included in the age, sex and BP matched cohort. The secondary selection procedure was undertaken by an observer blinded to the left ventricular mass measurements of the cohort.

Group differences between variables was explored using the paired t-test. Where non-normal data was compared, the Wilcoxon Rank Sum method was used. Differences in proportions between paired variables were explored by calculation of the $z$ statistic. A p-value of less than 0.05 was considered significant.

\section{Results}

Age and sex-matched population

A total of thirty-three age and sex-matched pairs were identified. The clinical data between groups are presented in Table 2.1. WCH patients were slightly 
heavier than controls, but not significantly so. Body mass index (BMI) was comparable across the two groups. A family history of hypertension was found more frequently in the WCH patient population, but there was no difference in reported family history of vascular disease. The incidence of cigarette smoking was comparable between the two groups.

Table 2.1. Clinical characteristics of oge and sex-matched patient population. Values are expressed as the mean ( $95 \%$ confidence intervals for the mean)

\begin{tabular}{lccc}
\hline & Cases & Controls & p-value \\
\hline$n$ & 33 & 33 & \\
Age (yrs) & 40.3 & 40.1 & \\
Sex (M/F) & $9 / 24$ & $9 / 24$ & \\
Weight (kgs) & $73.6(67.9-79.4)$ & $70.0(65.9-74.1)$ & 0.20 \\
Height (cm) & $166.6(162.8-170.4)$ & $168.8(165.8-171.7)$ & 0.23 \\
Family history of hypertension & $21 / 33$ & $15 / 33$ & $\mathrm{~ns}$ \\
History of vascular disease & $15 / 33$ & $17 / 33$ & $\mathrm{~ns}$ \\
Smoker & $13 / 33$ & $13 / 33$ & $\mathrm{~ns}$ \\
\hline
\end{tabular}

Intra-observer error for echocardiographic parameters was small; ANOVA iesiling siluwed' no over-ail ailference in me mean LVM caiculated trom the three sets of measurements. Absolute differences across measurements did differ significantly from zero, with a mean difference of 2.4 grams $(95 \%$ confidence interval 2.0-2.8). Accordingly, although significant, the absolute intra-observer variability was small.

The data pertaining to ABP are presented in Table 2.2. By definition, WCH patients had a significantly higher initial systolic and diastolic BP. Daytime and nighttime systolic BPs were significantly higher in the $\mathrm{WCH}$ patient group, although remaining within the normal range. There was no difference between the groups with respect to presence of nocturnal dipping of BP or heart rate. The LVMI is presented in Table 2.2. Both groups showed a LVMI within the normal range $\left(<110 \mathrm{~g} / \mathrm{m}^{2}\right)$, but the LVMI for white coat hypertensives was significantly greater than controls. 
Table 2.2. Blood pressure and left ventricular mass data from age abd sex-matched cases and controls. All BP data are expressed as $\mathrm{mmHg}$. Data values are expressed as means ( $95 \%$ confidence intervals for the mean).

\begin{tabular}{lccc}
\hline & Cases & Controls & Pvolue \\
\hline Clinic SBP & $162.2(157.8-166.5)$ & $110.6(106.1-115.1)$ & $<0.0001$ \\
Clinic DBP & $102.0(98.9-105.1)$ & $69.6(66.7-72.5)$ & $<0.0001$ \\
Day SBP & $125.4(123.3-127.5)$ & $117.1(113.8-120.3)$ & $<0.001$ \\
Day DBP & $77.6(76.0-79.2)$ & $75.0(72.9-77.1)$ & 0.051 \\
Night SBP & $101.6(98.9-104.3)$ & $106.9(104.0-109.8)$ & 0.01 \\
Night DBP & $62.9(60.8-64.9)$ & $60.5(58.5-62.4)$ & 0.09 \\
LVMI $\left(9 . \mathrm{m}^{2}\right)$ & $99.0(88.2-109.8)$ & $78.3(71.3-85.3)$ & 0.001 \\
\hline
\end{tabular}

Age, sex and blood pressure matched population

Secondary matching identified 20 age, sex and BP matched pairs. BMI was not significantly different between the groups, and they were comparable for other clinical features (Table 2.3). The BP data are presented in Table 2.4. The groups were similar for 24-hour BP parameters, and only differed in the initial BP profile, with the WCH group having a higher initial systolic and diastolic pressure. End-organ data from the two groups shows persistence of the differences in left ventricular muscle mass index (Table 2.4), with the WCH group demonstrating significantly higher LVMI. A multiple regression model was fitted to the data with LVMI as the dependent variable, to determine possible confounding by the independent variables daytime and night-time systolic and diastolic BP, age, BMI, height, weight and sex. Additionally, the presence or absence of WCH was entered into the model as a covariate. The only significant predictors in the model were the presence or absence of $\mathrm{WCH} p=0.011)$, and age $(p=0.01)$.

Table 2.3. Clinical characteristics of age, sex and BP-matched patient population. Values are expressed as the mean ( $95 \%$ confidence intervals for the mean)

\begin{tabular}{lccc}
\hline & Cases & Controls & p value \\
\hline $\mathrm{N}$ & 20 & 20 & \\
Age (yrs) & 40.2 & 40.8 & \\
Sex (M/F) & $10 / 10$ & $10 / 10$ & \\
Weight (kgs) & $79.9(72.5-87.4)$ & $75.0(70.0-80.0)$ & 0.14 \\
Height (cm) & $170.5(165.5-175.6)$ & $173.1(169.2-176.9)$ & 0.37 \\
Family history of hypertension & $5 / 20$ & $5 / 20$ & $\mathrm{~ns}$ \\
History of vascular disease & $9 / 20$ & $10 / 20$ & $\mathrm{~ns}$ \\
Smoker & $8 / 20$ & $9 / 20$ & $\mathrm{~ns}$ \\
\hline
\end{tabular}


22 Chapter 2

Table 2.4. Blood pressure data from age, sex and BP-matched cases and controls. All BP data are expressed as $\mathrm{mmHg}$. Data values are expressed as means $195 \%$ confidence intervals for the mean)

\begin{tabular}{lrccc}
\hline & \multicolumn{1}{c}{ Cases } & Controls & $p$ value \\
\hline Clinic SBP & $160.2(154.6-165.8)$ & $116.2(111.5-120.9)$ & $<0.0001$ \\
Clinic DBP & $102.3(98.1-106.5)$ & $73.0(70.2-75.8)$ & $<0.0001$ \\
Day SBP & $125.2(122.2-128.0)$ & $123.0(120.3-125.8)$ & 0.17 \\
Day DBP & $77.2(75.0-79.4)$ & $78.8(76.8-80.8)$ & 0.18 \\
Night SBP & $108.0(104.7-111.3)$ & $105.3(102.9-107.7)$ & 0.10 \\
Night DBP & $63.1(60.6-65.7)$ & $62.8(60.7-64.9)$ & 0.81 \\
LVMI $\left(g . \mathrm{m}^{2}\right)$ & $101.1(87.2-115.0)$ & $81.0(70.6-91.5)$ & 0.021 \\
\hline
\end{tabular}

\section{Discussion}

White coat hypertension as a clinically distinct entity has been recognised for some time. ${ }^{21,22}$ As many as $20 \%$ of patients presenting for ABP monitoring with an elevated clinic measured BP may have a normal 24-h BP profile. ${ }^{23}$ The debate cantinues as to whether the clinical condition of WCH represents a true pathological state, with associated morbidity, or a benign manifestation of a reactive sympathetic nervous system. ${ }^{24}$

There has been recent speculation that WCH is not an entirely benign entity. Left ventricular mass has been shown to be higher in elderly white coat hypertensives than in normal controls. ${ }^{4,7}$ However the literature is at variance on the subject, with other reports suggesting that no significant left ventricular remodelling occurs in these patients. "It is interesting to note that previous comparative studies of WCH vs. normotension have shown higher 24-hour BPs in the WCH group. ${ }^{0,7,11}$ This would at least suggest that within the normal range, WCH patients have a higher 24-hour BP load, occupying a higher pressure stratum than normotensives. The subtle changes in left ventricular mass could be accounted for by this BP discrepancy. ${ }^{13}$ If this was the case, then one would expect that differences between normo- and white coat hypertensives with regard to target organ changes would disappear when the groups are further controlled for 24-hour BP. Indeed, two such studies, 9,10 comparing left ventricular mass between normotensive and WCH groups, where 24-hour BP was comparable across the two groups, showed no difference in structural heart changes. On the other hand, Glen et al ${ }^{3}$ in a similarly designed study, with BP equivalence between the normal and WCH groups, showed evidence of functional cardiac derangement in the WCH group. This last study has however been criticised for having a very high cut-off point for the difference between normotension and hypertension, at $95 \mathrm{mmHg}$ diastolic. ${ }^{25,26}$ As discussed by Verdecchia et al., ${ }^{27}$ a high cut-off point may result in patients with borderline hypertension being included in the definition of WCH. As a result, end-organ damage may be ascribed to patients given the qualitative diagnosis of $\mathrm{WCH}$, when in fact it is the quantitative, continuous variable of BP that is responsible 
for end-organ changes. Our study specifically compares cardiac muscle mass between normal patients and white coat patients, and removes the possible confounding effect of differences in BP between the two groups. The fact that differences in muscle mass persisted when BP differences were removed from the equation is strong evidence that white coat hypertensives are indeed different from their normotensive counterparts.

Left ventricular hypertropy (LVH) has been well documented as an indicator of a poor prognosis in patients with hypertension. ${ }^{28}$ It is possible that even with our strict matching of BP, minor differences in measured pressure might, over a protracted time period, give rise to the observed differences in left ventricular mass, but the minimal differences between the populations would make this very unlikely.

What aetiological mechanisms may be at work to cause cardiac changes in the presence of WCH but in the absence of sustained elevation of BP? Firstly, transient stress-related increases in BP, occurring throughout the course of the day may account for reactive changes in the vascular architecture of the heart, while not altering the mean BP load, as measured on 24-hour ABP monitoring. Thus, an increase in BP variability may account for the changes in target organs. ${ }^{29}$ However, a number of studies have failed to show significant BP lability in patients with $\mathrm{WCH}^{30.31}$ Secondly, the presence of $\mathrm{WCH}$ may be a manifestation of an underlying dysfunctional sympathetic nervous system. ${ }^{32,33}$ Left ventricular muscle hypertrophy has been ascribed to trophic activity of the sympathetic nervous system. ${ }^{34}$ Again, however, sympathetic anomalies have not been definitively proven in $\mathrm{WCH} .{ }^{29.35}$ Finally, patients with $\mathrm{WCH}$ may have an underlying genetic propensity to an increased stress responsiveness of $\mathrm{BP}$. This genetic tendency may also be expressed in subtle abnormalities of cardiac modelling. It is already known that children of hypertensive parents, without overtly elevated BP, may show structural cardiac muscle hypertrophy. ${ }^{36}$ A prospective study showing that white coat hypertensives progress to sustained hypertension would provide good supportive evidence for this latter interpretation, and some evidence for this does exist. ${ }^{37}$

With respect to this study, it is always a concern that a retrospective case control study will be open to selection bias. It is possible that a particularly severe cohort of white coat hypertensives, with LVH, were selectively identified. However, the decision to perform the echocardiography was a protocol driven one, based on the referral BP, and without knowledge of the ABP monitoring result. The likelihood therefore of particularly a pathological cohort being identified is small.

A prevalence rate of $20 \%$ for $\mathrm{WCH}$ means that a significant number of patients in the community have a form of BP abnormality which carries a relatively low risk. ${ }^{38}$ Our findings would concur with this interpretation. However, our results also suggest that WCH does describe a group of patients with a cardiovascular profile that is different from normal.

The only prospective study to date ${ }^{25.39}$ had a relatively short follow-up period, and was unlikely to have shown either progression to sustained hypertension in 
24 Chapter 2

white coat hypertensives over this time period, and therefore would have been unlikely to have shown an excess of morbidity in these patients.

Further data are therefore required to determine the prognostic significance of our findings, with regard to mortality and end-stage organ failure. 


\section{References}

1. Pickering TG. White coat hypertension. Cur Opin Nephrol Hypertens 1996; 5; 192 198.

2. Mancia G, Zanchetti A. Untitled - reply to correspondence. J Hypertens 1997; 15: 100.

3. Glen SK et al. White coat hypertension as a cause of cardiovascular dysfunction. Lancet $1996 ; 348$ : 654-657.

4. Kuwajima I, Suzuki Y, Fujisawa A, Kuramoto K. Is white coat hypertension innocent? Structure and function of the heart in the elderly. Hypertension 1993; 22:826-831.

5. Burnier $M$ et al. Renal sodium handling in patients with untreated hypertension and white coat hypertension. Hypertension 1993; 23: 496-502.

6. Cerasola $G$ et al. White coat hypertension and cardiovascular risk. J Cardiovasc Risk 1995; 2 : 545-549.

7. Cardillo C, De Felice F, Campia U, Folli G. Psychophysiological reactivity and cardiac end-organ changes in white coat hypertension. Hypertension 1993; 21:836-844.

8. Hoegholm A, Bang LE, Kristensen KS, Nielsen JW, Holm J. Microalbuminuria in 411 untreated individuals with established hypertension, white coat hyper-tension, and normotension. Hypertension 1994; 24:101-105.

9. Pierdomenico SD et al. Target organ status and serum lipids in patients with white coat hypertension. Hypertension 1995; 26: 801-807.

10. Verdecchia $P$ et al. White coat hypertension and white coot effect. Similarities and differences. Am J Hypertens 1995; 8: 790-798.

11. Cavallini MC et al. Is white coat hypertension associated with arterial disease or left ventricular hypertrophy? Hypertension 1995; 26: 413-419.

12. Gosse P, Promax H, Durandet P, Clementy J. "White Coat" Hypertension; no harm for the heart. Hypertension 1993; 22: 766-770.

13. Coats A. Is white coat hypertension innocent? [letter]. Hypertension 1993; 22: 816 .

14. O'Brien E et al. Twenty four hour ambulatory blood pressure in men and women aged 17 to 80 years: the Allied Irish Bank Study. J Hypertens 1991; 9: 355-360.

15. Devereux RB et al. Standardisation of $M$-mode echo-cardiographic left ventricular anatomic measurements. J Am Coll Cardiol 1984; 4: 1222-1230.

16. Petrie JC et al. Recommendations on blood pressure measurement: British Hypertension Society (second edition). British Medical Journal Books: London UK, 1990.

17. O'Brien E, Mee F, Atkins N, O'Malley K. Accuracy of the Spacelabs 90207 determined by the British Hypertension Society Protocol. J Hypertens 1991; 9: 573 574.

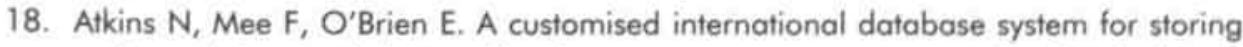
and analysing ambulatory blood pressure measurements and related data Abstract. J Hypertens 1994; 12: S23. 
$26 \mid$ Chapter 2

19. Stoessen $\mathrm{J}$ et al. Reference values for the ambulatory blood pressure and the blood pressure measured at home: a population study. J Hum Hypertens 1991; 5:355. 361.

20. Staessen JA, Fagard R, Thiis L, Amery A, and the participants in the Fourth International Consensus. Conference on 24-hour Ambulatory Blood Pressure Monitoring. A consensus view on the technique of ambulatory blood pressure monitoring. Hypertension 1995; $26: 912.918$.

21. Ayman D, Goldshine AD. Blood pressure determinations by patients with essential hypertension. Am J Med 1940; 200: 465-474.

22. Lemmer B. White coat hypertension: Described more than 250 years ago [letter]. Am J Hypertens 1995; 8:437.

23. Pickering TG et al. How common is white coat hypertension? JAMA 1988; 259: 225-228.

24. Zimmerman RS, Frohlich ED. Stress and hypertension. J Hypertens 1990; 8 (Suppl 4): S103-S107.

25. Krakoff LR, Phillips RA. White coat hypertension [letter]. Lancet 1996; 348: 14431444 .

26. Kristensen KS, Hoegholm A. White coat hypertension [letter]. Lancet 1996; 348: 1444.

27. Verdecchia $P$ et al. White coat hypertension [letter]. Lancet 1996; 348: 1444-1445.

28. Levy D et al. Prognostic implications of echocardio-graphically determined left ventricular mass in the Framingham heart study. N Engl J Med 1990; 322:1561. 1566.

29. Parafi $G$ et al. Blood pressure variability, cardiovascular risk and anti-hypertensive treatment. J Hypertens Suppl 1995; 13: S27-S34.

30. Floras JS. Cuff and ambulatory blood pressure in subjects with essential hypertension. Lancet 1981; ii: 107-109.

31. Parati $G$ et al. Limitations of laboratory stress testing in the assessment of subjects' cardiovascular reactivity to stress. J Hypertens 1986; 4 (Suppl 6): S51-S53.

32. Middeke $M$, Lemmer B. Office hypertension: abnormal blood pressure regulation and increased sympathetic activity compared with normotension. Blood Pressure Monitoring 1996; 1: 403-407.

33. Weber MA, Nuetel JM, Smith DH, Graettinger WF. Diagnosis of mild hypertension by ambulatory blood pressure monitoring (comments). Circulation 1994; 90:2291. 2298.

34. Ostman-Smith I. Reduction by oral propranolol treatment of left ventricular hypertrophy secondary to pressure-overload in the rat. $\mathrm{Br} J$ Pharmacol 1995; 116:2703-2709.

35. Saito I et al. Comparison of clinic and home blood pressure levels and the role of the sympathetic ner-vous system in clinic-home differences. Am J Hypertens 1990; 3: $219 \cdot 224$,

36. Nielsen JR, Oxhoi $H$, Fabricius J. Left ventricular structural changes in young men at increased risk of developing essential hypertension. Assessment by echocardiography. Am J Hypertens 1989; $2: 885$.

37. Bidlingmeyer I et al. Isolated office hypertension: a prehypertensive state? I Hypertens 1996; 14:327-332. 
White coat hypertension and target-organ damoge

38. Myers MG, Reeves RA, Oh PI, Joyner CD. Overtreatment of hypertension in the community? J Hypertens 1996; 9: 419-425.

39. Verdecchia $\mathbf{P}$ et al. Ambulatory blood pressure. An independent predictor of prognosis in essential hypertension. Hypertension 1994; 24: 793-801. 

28 


\section{Chapter 3}

Left ventricular hypertrophy and renal impairment are associated with reduced nocturnal blood pressure decline, even in adequately treated hypertensives Atkins N, Lyons SP, Owens PE, de Leeuw PW, O'Brien ET 


\section{Abstract}

\section{Introduction}

Patients with absence of a nocturnal blood pressure fall (non-dippers) may be at higher risk for cardiovascular and renal target organ damage. Left ventricular hypertrophy (LVH) and nephropathy have been reported to occur more frequently in non-dippers.

\section{Objective}

To assess whether a relation between nocturnal decline in blood pressure (BP) and target organ damage is still present during treatment, we determined the presence of LVH and renal damage in 479 treated hypertensives, selected from a database which comprises patients referred for treatment of hypertension to a large regional hospital.

\section{Methods}

LVH was determined by echocardiography. Nephropathy was assessed by measuring serum creatinine, creatinine clearance and microalbuminuria. For analysis, patients were divided in three groups: adequately treated (SBP $<135$ and $D B P<85 \mathrm{mmHg}, n=87$ ), borderline treated (intermediate BP, $n=193$ ), and inadequately treated (SBP>140 and DBP $>90 \mathrm{mmHg}, n=199$ ). Each BP group was subdivided into tertiles based of the degree of dipping.

\section{Results}

The mean percentage noctural fall in BP was $10 \%, 12 \%$, and $16 \%$ in the adequately treated, borderline, and inadequately treated group, respectively. Patients in the inadequately and bordeline treated groups, as well as those with blunted nocturnal fall in the adequately treated group had significantly higher left ventricular mass index (LVMI). Only adequately treated subjects had a normal LVMI. No differences in renal function were observed between these groups. Reduced nocturnal dipping was associated with both a higher LVMI and impaired renal function.

\section{Conclusion}

In treated hypertensives, both LVMI and renal function are related to the degree of nocturnal fall in BP, but only cardiac damage is associated with overall inadequate treatment as based on daytime BP measurements. This suggests that antihypertensive treatment may not necessarily reduce cardiovascular risk and that the kidney is more resistant to hypertension-related damage than the heart. 


\section{Introduction}

Several lines of evidence indicate that 24-hour ambulatory blood pressure (BP) is a far better predictor for target organ damage and cardiovascular risk than office blood pressure. In particular, nighttime pressure and the degree of nocturnal dipping are strongly related to prognosis in untreated essential hypertension. ${ }^{1,2}$ Recently, Verdecchia et al. also demonstrated in treated hypertensives that ambulatory blood pressure monitoring (ABPM) is superior to office measurements for prediction of subsequent cardiovascular disease. ${ }^{3}$ However, despite considerable improvements in antihypertensive therapy, cardiac and renal complications continue to occur. This may be related to insufficient reversal of target organ damage. Surprisingly, though, very little information is available with respect to the relationship between 24-hour or nocturnal BP and target organ damage in treated hypertensive patients. Also, it is not well known whether the degree of target organ damage in adequately treated hypertensives is proportional to the achieved level of blood pressure or not. This prompted us to address this question in more detail. Accordingly, we examined the association of ambulatory recorded blood pressure with cardiac and renal damage in a large group of treated patients with essential hypertension. Cardiac changes were assessed by echocardiography and renal damage was estimated from serum creatinine, creatinine clearance and microalbuminuria.

\section{Patients and Methods}

\section{Study population}

Patients were identified from a search in the hypertension database of the Blood Pressure Unit from the Beaumont Hospital in Dublin (Ireland), which comprises patients referred to the hospital for treatment of hypertension. Patients referred to this service routinely have echocardiography performed within one week of the ABP monitor being applied. On the day the ABPM was executed, office BP was measured twice in sitting position. A check list was kept regarding the occurrence of familial hypertension in the first degree and the presence of cardiovascular morbidity due to hypertension. Furthermore, blood samples were taken for determination of serum creatinine, total cholesterol, HDL cholesterol, serum triglycerides, sodium, potassium, chloride, urate, glucose, urea and urine samples for protein, glucose, and microalbuminuria. All variables were determined by the standard procedures used at the routine laboratory. Microalbuminuria was measured using the dipstick method. Patients were only selected if they were treated with antihypertensive drugs. Patients were excluded if the above definition was not met, and if the routine tests were not adequately 
performed. Furthermore, patients with a serum creatinine higher than $150 \mu \mathrm{mol} / \mathrm{l}$ were excluded from the study. After these criteria were applied, we included 479 treated hypertensive patients in this study.

\section{Echocardiography}

Echocardiography was performed by a trained technician using a standard $2.5 \mathrm{MHz}$ transducer applied to the chest in the parasternal long and short axis planes for measurements of wall thickness and chamber size. Left ventricular mass (LVM) was calculated using the formula of Devereux ef al. ${ }^{4}$, and was indexed for body surface area. To ensure there was no systematic observer bias, the $M$-mode tracings were printed from each of the videotaped studies. A trained technician who was blinded to the patients then manually measured the chamber dimensions.

\section{Definitions and statistics}

For analysis, patients were devided in three groups: adequately treated (defined as daytime systolic BP $<135 \mathrm{mmHg}$ and daytime diastolic BP $<85 \mathrm{mmHg}$ ), borderline treated $(135 \mathrm{mmHg}\rangle=$ daytime systolic $\mathrm{BP}=<140 \mathrm{mmHg}$ and 85 $\mathrm{mmHg}_{\mathrm{g}}>=$ daytime diastolic $\mathrm{BP}=<90 \mathrm{mmHg}$ ), and inadequately treated

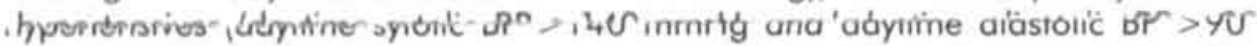
$\mathrm{mmHg}$ ), as measured by ABPM. Daytime was defined from 9:00 a.m. till 9:00 p.m. and nighttime as 1:00 a.m. till 6:00 a.m. Nocturnal fall in BP was calculated using the formula: [(MAP day - MAP night) / MAP day] $\times 100 \%$, in which MAP represents mean arterial pressure. On the basis of the degree of nocturnal fall each treatment group was further subdivided into tertiles. Creatinine clearance was calculated according to the formula of Cockcroft and Gault. 5

The data pertaining to the cases were uploaded into a commercially avialable spreadsheet, and this was in turn uploaded into a statistical program (SPSS Inc., Chicago, Illinois, USA). Differences between and within groups for normally distributed variables were explored with analysis of variance (one-way ANOVA) and, if necessary, followed by a t-test for independent samples. Differences in proportions were explored by calculation of the z-statistics. Bonferonni's method for correction of multiple testing was applied. Determinants of dipping were analyzed by means of linear regression. Unless indicated otherwise, all data are presented as mean \pm standard deviation (SD). A p-value less than 0.05 was considered statistically significant.

\section{Results}

The main characteristics of all subjects were as follows: $37 \%$ were males, body mass index (BMI) $28 \mathrm{~kg} \cdot \mathrm{m}^{2}$, office systolic BP $166 \pm 26 \mathrm{mmHg}$ and diastolic BP $95 \pm 13 \mathrm{mmHg}$, mean daytime ambulatory systolic BP $148 \pm 19 \mathrm{mmHg}$ and 
diastolic BP $90 \pm 12 \mathrm{mmHg}$, mean nighttime ambulatory systolic BP $131 \pm 19$ $\mathrm{mmHg}$ and diastolic BP $76 \pm 12 \mathrm{mmHg}$. Patients had been treated for a median period of 2.5 years (range 0.9 to 3.2 years) with the following medications: diuretics $(39 \%)$, beta-blockers $(38 \%)$, angiotensin-converting enzyme inhibitors $(34 \%)$, calcium channel blockers (22\%), angiotensin II receptor blockers $(7 \%)$, and other drugs $(6 \%)$. Forty percent of the patients received more than one antihypertensive drug (Figure 3.1)

The data concerning the nocturnal fall of BP and the parameters for cardiorenal target organ damage, subdivided according to treatment efficacy, are shown in Table 3.1. The percentage of dipping was highest in the inadequately treated group $(p<0.001)$. This latter group had, by definition, the highest daytime MAP.

Table 3.1. Results of ambulatory blood pressure measurements and cardiorenal target organ damage in 479 treated hypertensive patients, subdivided in three groups on the basis of treatment efficacy

\begin{tabular}{lcccc}
\hline & Adequate $^{*}$ & Borderline & Inadequate & p-value\# \\
\hline Number & 87 & 193 & 199 & \\
Age (years) & $53 \pm 14$ & $55 \pm 12$ & $53 \pm 11$ & $\mathrm{n} . \mathrm{s}$. \\
Daytime MAP $(\mathrm{mmHg})$ & $92 \pm 5$ & $105 \pm 6$ & $122 \pm 10$ & $<0.001$ \\
Nighttime MAP $(\mathrm{mmHg})$ & $83 \pm 9$ & $92 \pm 11$ & $103 \pm 14$ & $<0.001$ \\
Dipping (\%) & $10 \pm 10$ & $12 \pm 10$ & $16 \pm 9$ & $<0.001$ \\
Serum creatinine $(\mu \mathrm{mol} / \mathrm{l})$ & $93 \pm 24$ & $92 \pm 24$ & $91 \pm 21$ & $\mathrm{n} . \mathrm{s}$ \\
Creat. Clearance & $83 \pm 24$ & $84 \pm 28$ & $88 \pm 29$ & $\mathrm{n} . \mathrm{s}$ \\
Microalbuminuria $(\mu \mathrm{g} / \mathrm{l})$ & $25 \pm 30$ & $28 \pm 29$ & $34 \pm 34$ & $\mathrm{n} . \mathrm{s}$ \\
LVMI $\left(\mathrm{g} / \mathrm{m}^{2}\right)$ & $109 \pm 38$ & $124 \pm 43$ & $130 \pm 38$ & $<0.001$ \\
\hline
\end{tabular}

- for definition of treatment groups see method section; \# one-way ANOVA; n.s. indicates not statistically significant; LVMI indicates left ventricular mass index.

However, nighttime MAP in this group was also significantly higher in comparison to the two other groups $(p<0.001)$. Interestingly, subjects in this inadequately treated group more frequently used an angiotensin-converting enzyme inhibitor in comparison to the adequately treated group $(p=0.03)$, whereas $\beta$-blockers $(p=0.004)$ and combination treatments $(p=0.01)$ were more frequently used in the adequately treated group (Figure 3.1).

Between the treatment groups we did not observe significant differences with regard to the measures for renal damage, i.e. serum creatinine, creatinine clearance, and microalbuminuria (Table 3.1). However, if treatment groups were further subdivided into tertiles based on the degree of nocturnal dipping of BP (Table 3.2), subjects with the smallest difference between day- and nighttime BP (Figure 3.2, panel A, tertile III) had a significantly lower creatinine clearance compared to the other two tertiles in all three treatment groups $(p=0.03$, $p=0.003$, and $p=0.05$, respectively). By multiple linear regression creatinine clearance was significantly associated with the degree of dipping $(\beta=0.51$, $\mathrm{p}<0.001$ ) but not with treatment class. In other words, the amount by which BP fell during the night had a significant effect on creatinine clearance, but whether 
or not patients were adequately treated had no further effect on this parameter of renal function.

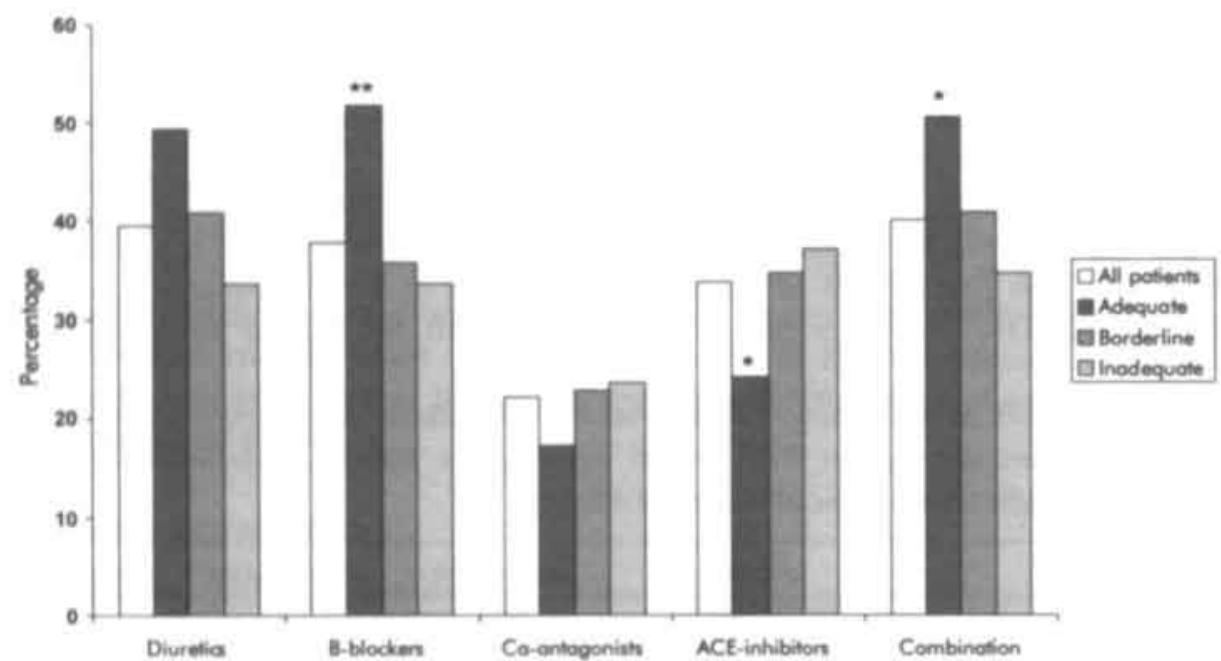

Figure 3.1. Frequency distribution of four main classes of antihypertensive drugs, represented for the total group $(n=479)$ and subdivided in freatment efficacy groups: adequately treated, borderline treated, inadequately treated ${ }^{\mathrm{s}}$.

\& for definition of treatment groups see method section; \# combination therapy indicates treatment with two or more antihypertensive drugs;

$\cdot 0.01 \leq \mathrm{p}<0.05 ; \cdots p<0.01$.

Table 3.2. Degree of noctural fall in blood pressure subdivided in tertiles per treatment group.

\begin{tabular}{lcccc}
\hline & Tertile I & Tertile II & Tertile III & p-value* \\
\hline Adequately treated (SBP $<135 \mathrm{~mm} \mathrm{Hg}$ and DBP $<85 \mathrm{mmHg}$ ) & & \\
\hline Number & 29 & 29 & 29 & \\
Dipping (\%) & $19 \pm 4$ & $11 \pm 2$ & $-1 \pm 8$ & $<0.001$ \\
\hline Borderline treated & $(135 \leq \mathrm{SBP} \leq 140 \mathrm{mmHg}$ & and $85 \leq \mathrm{DBP} \leq 90 \mathrm{mmHg})$ & \\
\hline Number & 64 & 64 & 65 & \\
Dipping (\%) & $22 \pm 4$ & $13 \pm 5$ & $2 \pm 7$ & $<0.001$ \\
\hline Inadequately treated (SBP $>140 \mathrm{mmHg}$ and DBP $>90 \mathrm{mmHg})$ & 67 & \\
\hline Number & 66 & 66 & $6 \pm 5$ & $<0.001$ \\
\hline Dipping (\%) & $25 \pm 4$ & $16 \pm 3$ & $6 \pm 5$
\end{tabular}

- one-way ANOVA.

Results with regard to the presence of LVH were as follows: subjects with inadequately treated hypertension had the highest LVMI in comparison to the adequately treated group (Table $3.1 ; \mathrm{p}<0.001$ ). Moreover, as shown in Figure 3.2, panel B, within each treatment group there was a gradual, significant increase in LVMI going from subjects with the greatest percent dipping (tertile I) 
to those who hardly changed at night (tertile III). By multiple linear regression we found a significant negative association between LVMI and the percentage of dipping in the whole group $(\beta=-0.52, p=0.007)$. When the degree of dipping and treatment class were introduced into the regression model, both remained statistically significant, indicating that inadequate treatment produces extra damage over and above that associated with a low dipping state. No association was found between LVMI and creatinine clearance.

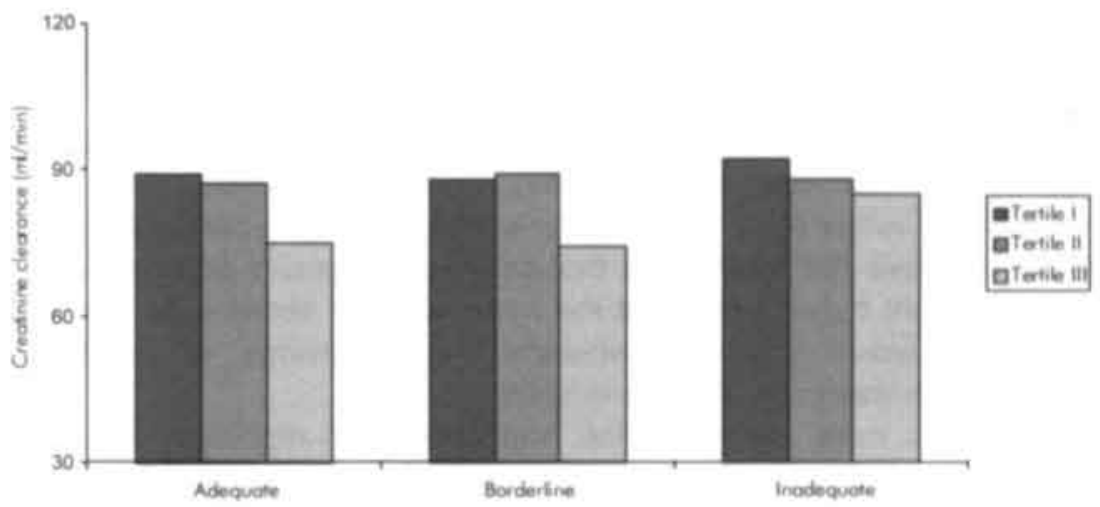

Figure 3.2. Creatinine clearance (panel A) and left ventricular mass index (panel B) represented in tertiles from the percentage of nocturnal fall in blood pressure per treatment efficacy group ${ }^{8}$.

$\&$ for definition of treatment groups see method section.

\section{Discussion}

This study shows that both an increase in LVMI and a reduction in creatinine clearance are associated with a lesser degree of nocturnal blood pressure fall in treated hypertensive patients. Moreover, left ventricular hypertrophy, but not nephropathy, was associated with daytime BP measurements, i.e. subjects who were adequately treated had a significantly lower left ventricular mass than those who were not, but similar renal function.

Lowering of blood pressure in hypertensives should maximize patients' wellbeing and simultaneously lower the risk for pressure-related cardiovascular and renal complications. Therefore, our study was performed to evaluate if treated essential hypertensives achieve an acceptable lowering of their risk for the development of target organ damage. To this end, we assessed the presence of target organ damage in the heart and the kidneys of patients who had adequate or inadequate BP lowering during the day and the night. Data from controlled trials on antihypertensive treatment suggest that blood pressure goals, especially a systolic daytime level below $140 \mathrm{mmHg}$, are hardly met. ${ }^{6}$ Our data suggest 
that this is particularly deleterious for the heart, since only adequate treatment reduced LVMI significantly. With respect to hypertension-induced renal damage, one could have an even more pessimistic view, since renal function was similar in all groups irrespective of the adequacy of treatment. Apparently, adequate treatment does not lead to improvement of renal function as it does for the heart. However, if cannot be excluded from our data that the relative insensitivity of the kidney for lowering BP is a consequence of pre-existing nephropathy, present already before the start of treatment. Still, this possibility seems less likely, because LVMI had regressed, or was normal, in the adequately treated group in our study, and, generally, nephropathy develops as a rather late complication. Therefore, our data suggest that perhaps different pathophysiological mechanisms are involved in the development or prevention of target organ damage in the kidney and in the heart. This puts the observations of Collins et al. in perspective that treating hypertension improves prognosis, but does not return it to that of a normotensive population.? In this respect, one might hypothesize that the heart is more sensitive to the absolute height of the blood pressure, whereas renal damage is predominantly dependent on the variability of hypertension.

Only few studies have examined the implications of nighttime BP on target organ damage. ${ }^{6-10}$ Morfis ef al. have shown that nocturnal BP is a strong predictor of LVMI in treated hypertensives and normotensives. Grandi ef al. have shown in never-treated essential hypertensives that a fall in nocturnal BP by more than 10\% from daytime BP was not related to left ventricular morphology, and concluded that the nondipping status established on the basis of a single 24-hour BP monitoring does not identify hypertensive patients with greater cardiovascular damage. Indeed, in our study we observed a significantly higher degree of nocturnal BP fall in the inadequately treated group with the highest LVMI. However, the nighttime BP in this group was also significantly higher. This probably indicates that it is the absolute nighttime BP level, and not the percentage of dipping of BP, that is important for the development of cardiorenal target organ damage. Indeed, studies in rats have shown that blood pressure levels during sleep are more important for the development of cardiac hypertrophy. "

A limitation of our study may be the duration of antihypertensive treatment. However, patients in our study were treated for a minimum period of 11 months (median 30 months), which reduces the probability that the duration of the treatment confounded our results.

The differential effects of drugs on the target organ damage may be another limitation of this study. It is possible that different classes of drugs had another outcome on day and night blood pressure, and changed the "dipper-status": short-acting drugs may convert a person into a 'non-dipper', whereas longacting drugs or taking drugs before bedtime may convert someone into a 'dipper'. In other words, $\beta$-blockers may cause a non-dipper status, and angiotensin-converting enzyme inhibitors and angiotensin II receptor blockers can induce a dipper-status. ${ }^{12}$ In our study the use of $\beta$-blockers was significantly higher in the adequately treated group, and the use of angiotensin-converting 
enzyme inhibitors was higher in the inadequately treated group. This indicates that, if differences in drug treatment influenced our results, it would make the conclusions of this study even stronger.

In conclusion, our data suggest that treatment of hypertension has disparate effects on the degree of target organ damage in heart and kidneys. On the basis of our results, we propose that the nighttime level of BP and not necessarily the degree of nocturnal fall in BP is the more important variable. We may have reached the point in which we have to give due attention to a 24 -hour lowering $\mathrm{BP}$ strategy in order to prevent target organ damage to develop. 


\section{References}

1. Verdecchia P, Porcellati C, Schillaci G, Borgioni C, Ciucci A, Battistelli M, et al. Ambulatory blood pressure. An independent predictor of prognosis in essential hypertension. Hypertension 1994;24:793-801.

2. Staessen JA, Thiis L, Fagard R, O'Brien ET, Clement D, de Leeuw PW, et al. Predicting cardiovascular risk using conventional vs ambulatory blood pressure in older patients with systolic hypertension. Systolic Hypertension in Europe Trial Investigators. Jama 1999;282:539-546.

3. Verdecchia P, Reboldi G, Porcellati C, Schillaci G, Pede S, Bentivoglio M, et al. Risk of cardiovascular disease in relation to achieved office and ambulatory blood pressure control in treated hypertensive subjects. J Am Coll Cardiol 2002;39:878. 885.

4. Devereux RB, Lutas EM, Casale PN, Kligfield P, Eisenberg RR, Hammond IW, et al. Standardization of $\mathrm{M}$-mode echocardiographic left ventricular anatomic measurements. J Am Coll Cardiol 1984;4:1222-1230.

5. Cockcroft DW, Gault MH. Prediction of creatinine clearance from serum creatinine. Nephron 1976;16:31-4I.

6. Mancia G, Grassi G. Systolic and diastolic blood pressure control in antihypertensive drug trials. J Hypertens 2002;20:1461-1464.

7. Collins R, Peto R, MacMahon S, Hebert P, Fiebach NH, Eberlein KA, et al. Blood pressure, stroke, and coronary heart disease. Part 2, Short-term reductions in blood pressure: overview of randomised drug trials in their epidemiological context. Lancet 1990;335:827-838.

8. Morfis L, Butler SP, Shnier RC, Howes LG. Nocturnal blood pressure predicts left ventricular mass index in normotensive elderly. Blood Press 2002;11:18-21.

9. Mancia G, Carugo S, Grassi G, Lanzarotti A, Schiavina R, Cesana G, et al. Prevalence of left ventricular hypertrophy in hypertensive patients without and with blood pressure control: data from the PAMELA population. Pressioni Arteriose Monitorate E Loro Associazioni. Hypertension 2002;39:744-749.

10. Grandi AM, Broggi R, Jessula A, Laurita E, Cassinerio E, Piperno F, et al. Relation of extent of nocturnal blood pressure decrease to cardiovascular remodeling in nevertreated patients with essential hypertension. Am J Cardiol 2002;89(10):1193-1196.

11. Morgan TO, Brunner HR, Aubert J-F, Wang Q, Griffiths C, Delbridge L. Cardiac hypertrophy depends upon sleep blood pressure: a study in rats. J Hypertens 2000;18:445-451.

12. Morgan TO. Is non-dipping status a predictor of cardiac morbidity? $\mathrm{J}$ Hypertens 2002:20:1469-1471. 


\section{Chapter 4}

\section{Blood pressure profile and its relation to cerebral white matter lesions in untreated hypertensives}

Rodriguez Hernández SA, van Boxtel MPJ, Kroon AA, Hofman P. de Leeuw PW 
$40 \mid$ Chopter 4

\section{Abstract}

Introduction

White matter lesions (WML) in the brain are common, both in normotensives and in hypertensives. The clinical significance of cerebral WML in hypertensives is not fully understood.

\section{Objective}

To investigate the relation between subcortical and periventricular WML and ambulatory blood pressure (BP) profiles in uncomplicated, untreated hypertensives.

\section{Methods}

In 96 untreated, uncomplicated hypertensive patients a MRI scan and 24-hour ambulatory BP monitoring was performed. The total volume of subcortical white matter lesions (sWML), the extent of periventricular white matter lesions ( $\mathrm{pWML}$ ), and the presence of subclinical cerebrovascular lesions were assessed. Characteristics of the ABPM were associated with presence and extent of the WML.

\section{Results}

The mean age of this group was $56 \pm 11$ years, $59 \%$ were males, the daytime mean arterial pressure (MAP) was $118 \pm 14 \mathrm{mmHg}$, and the nighttime MAP $102 \pm 14 \mathrm{mmHg}$. Nocturnal BP fall, nor absolute daytime or nighttime BP levels or BP load were associated with WML in the total population. When subjects were subdivided into tertiles based on the percentage of dipping of BP at night, a significantly higher prevalence of pWML was observed in the tertile with the highest percentage of dipping $143 \%$ versus $31 \%$ and $26 \%$ respectively; $p=0.04$ ). Daytime MAP was comparable in these subgroups. No association with any of the BP parameters was found for the sWML.

\section{Conclusion}

In untreated, middle-aged, hypertensive patients without clinical complications WML, especially sWML, are a frequent finding. No association between these subcortical lesions and the circadian BP profile was found. The prevalence of pWML was, however, much lower in patients with a reduced nocturnal BP fall. 


\section{Introduction}

Since the introduction of brain magnetic resonance imaging (MRI), the presence of cerebral lesions in the deep and subcortical white matter has been frequently reported. These so-called white matter lesions (WML) are a common finding in healthy, elderly people.' The presence of these WML has been taken as a prognostic factor for the development of stroke and cognitive impairment. ${ }^{2.4}$ However, the pathogenesis of WML is only poorly understood. Studies have shown that age, hypertension, diabetes mellitus, and a history of stroke or heart disease are the most important factors related to the presence of WML.' In essential hypertension, the presence of WML has been associated with the severity of hypertension ${ }^{5.6}$, the lack of blood pressure (BP) control in treated patients ${ }^{7.8}$, and an increased nocturnal BP decline. ${ }^{9.10}$ However, recent studies on ambulatory blood pressure monitoring (ABPM) and WML could not reproduce the latter finding, but rather stressed the association with the severity of high BP levels 11 and a reduced fall in nocturnal heart rate. ${ }^{6}$ Relative tachycardia during the night may point towards an increased sympathetic drive or imbalance between the parasympathetic and sympathetic autonomic nervous system.

Taking all available evidence together, most data appear to have been obtained in elderly people, or in a wide range of ages. Moreover, few studies distinguished between cortical and periventricular WML. To further clarify the relation between $\mathrm{BP}$ and $\mathrm{WML}$, we designed the present study in untreated, asymptomatic, middle-aged hypertensive patients. We aimed to investigate the association between the characteristics of the 24-hour ambulatory blood pressure profile and WML in the subcortical area and in the periventricular area of the brain in more detail.

\section{Patients and Methods}

\section{Study population}

Participants were selected from the hypertension outpatient clinic of the Department of Internal Medicine of the University Hospital of Maastricht. As part of the local protocol, ambulatory blood pressure measurements were performed in all patients. For the present analysis we selected 102 hypertensive patients who were between 40 and 80 years of ages, in whom no known cause of their hypertension was detected, and who were without apparent cardiovascular complications. This specific population was chosen because hypertension has been shown to be a major determinant of WML. Exclusion criteria were clinically documented ischemic or valvular heart disease, congestive heart failure, cerebrovascular accidents and/or transient ischemic attacks, chronic renal failure (serum creatinine $>150 \mu \mathrm{mol} / \mathrm{L}$ ), secondary hypertension, and claustro- 
phobia. In all patients antihypertensive medication was discontinued for three weeks prior to the measurements. None of the subjects developed adverse events during this drug-free period. All patients gave their informed consent in writing, after which they were scheduled to undergo ambulatory BP measurements off-medication and a cerebral MRI. This study was part of another survey investigating the relationship between neuropsychological function tests and hypertension-induced target organ damage of the brain. The study was approved by the local medical ethics committee.

\section{Blood Pressure Measurements and other covariates}

Noninvasive ambulatory blood pressure measurements (Spacelabs 92127, Redmond, WA) were obtained starting on a morning weekday. The cuff was applied to the non-dominant arm. For analysis, daytime was defined from 7:00 a.m. till 11:00 p.m. and nighttime from 1:00 a.m. till 6:00 a.m. The apparatus was programmed to perform blood pressure measurements every 15 minutes during the day and every 30 minutes during the night. Subjects were instructed to adhere to their normal daily activities and regular sleeping hours. At the time of their visit to the hospital, office blood pressure of patients was recorded by means of a sphygmomanometer and their body mass index (BMI) was calculated from simultaneously performed measurements of height and weight. Information on risk factors like smoking was obtained with a standardized questionnaire, which was checked by a physician during the interview.

\section{Neuroimaging}

MR images were acquired on a Philips Intera NT, operating at 1.5 tesla. A scout sequence was used to align the subsequent scans. The MR examination protocol consisted of an axial proton density (PD) sequence, an axial T2-weighted fast spin-echo (FSE) sequence, and an axial T2-weighted fluid-attenuated inversion recovery (FLAIR) sequence.

All MR scans were post-processed in order to obtain estimates of the total volume of subcortical white matter lesions (sWML), the extent of periventricular white matter lesions (pWML), and the presence of subclinical cerebrovascular lesions. WML were scored according to the guidelines of Achten ef al. ${ }^{12}$. For this purpose the axial PD, T2-weighted FSE, and FLAIR image stacks were aligned side by side on a computer screen using custom software (BIAS). ${ }^{13}$ This software allowed for systematic inspection of synchonized MRI images stacks and manual demarcation of regions of interest (ROI). At each axial level, sWML were scored using predefined region of interest (ROI) masks, i.e. circles with a diameter of 2 , 6 and $12 \mathrm{~mm}$, respectively. Lesions were identified on the FLAIR image and then traced on both other images. If a lesion was present on all images a predefined ROI mask was fitted over the lesion, which approximated its size most closely. After inspection and demarcation of all sWML's in a stack the program generated an output file with the number and size of all lesions at each level of the scan. This information was then transferred into a statistical package to yield a total sWML volume score for each patient. In this procedure, the ROI's were 
inflated to spheres with the same diameter, with corresponding volumes of 4.2 , 113 and $905 \mathrm{~mm}^{2}$, respectively. ${ }^{12}$ Subcortical WML were processed by one medical investigator after satisfactory intra-class correlations (ICC) between 0.81 and 0.98 had been reached ${ }^{14}$, based on the scoring of subsequent series of 10 random stacks by this investigator and an experienced neuroradiologist [PH]. Periventricular WML scores ranging between 0 and 3 were made for frontal and occipital periventricular regions ('caps') and the medial periventricular lining ('bands') separately, which were summed to an overall pWML score. ${ }^{12}$ The ICC for both raters of pWML based on all stacks was 0.87 (Pearson's $R=0.91$ ). Finally, the presence of other cerebrovascular lesions (lacunar infarctions) was identified by the neuroradiologist.

\section{Analysis of data}

The data pertaining to the cases were uploaded into a commercially available spreadsheet, and this was in turn uploaded into a statistical program (SPSS Inc., Chicago, III.). The nocturnal fall in BP (dipping) was calculated using the formula: [(MAP daytime - MAP nighttime) / MAP daytime] $\times 100 \%$, in which MAP represents mean arterial pressure. On the basis of the degree of the nocturnal fall the whole group of patients was divided into tertiles. Differences between and within tertiles for normally distributed variables were explored with analysis of variance (one-way ANOVA) followed, if necessary, by a t-test for independent samples. Data which showed a skewed distribution were log-transformed before analysis. Differences in proportions were explored by calculation of the z-statistics. Bonferonni's method for correction of multiple testing was applied. Deferminants of dipping were analyzed by means of (multiple) linear regression. Unless indicated otherwise, all data are presented as mean \pm standard deviation (SD). A p-value less than 0.05 was considered statistically significant.

\section{Results}

Four patients were excluded from analysis because they were unable to complete the entire MRI procedure and withdrew prematurely. In addition, from two patients the MRI data had been accidentaly deleted from the computer. The characteristics of the remaining subjects $(n=96)$ were as follows: $59 \%$ were males, $45 \%$ were current smokers and BMI averaged $29 \mathrm{~kg} / \mathrm{m}^{2}$. The average office BP was 166/95 mm mean daytime ambulatory BP $157 / 97 \mathrm{mmHg}$ and mean nighttime ambulatory BP $138 / 82 \mathrm{mmHg}$.

Table 4.1 shows the data for ambulatory BP and WML when patients were divided in tertiles based on the degree of their nocturnal blood pressure dip. No differences existed with respect to age, daytime MAP and daytime or nighttime heart rate. A significant difference in nighttime MAP was apparent, which was highest in the tertile with the least percentage dipping.

Only one subject of the whole group did not have sWML. The total volume of subcortical lesions was not different between the tertiles. Moreover, we did not 
find an association between ambulatory $\mathrm{BP}$ variables and either the presence or the volume of sWML. The prevalence of pWML, on the other hand, exhibited a significant trend across the tertiles and highest in the tertile with the lowest nighttime diastolic BP or greatest amount of dipping. By multiple linear regression, we found a significant positive association between dipping of BP and the prevalence of pWML. The introduction of other potentially confounding variables in the regression model did not alter this relationship. Interestingly, in this subset of asymptomatic patients, the prevalence of lacunar cerebrovascular infarctions was also significantly higher in the group with the biggest nocturnal BP dip. Although the score of pWML also tended to be highest in the tertile with the largest BP dip during the night, this failed to reach statistical significance.

Table 4.1. White matter lesions and characteristics of the ambulatory measured blood pressure in essential hypertensive patients subdived into tertiles on the basis of their percentage decline in nocturnal blood pressure.

\begin{tabular}{lcccl}
\hline & Tertile I & Tertile II & Tertile III & p-value* \\
\hline Number & 32 & 32 & 32 & n.s. \\
Age (years) & $59 \pm 9$ & $54 \pm 10$ & $56 \pm 12$ & n.s. \\
Daytime MAP (mmHg) & $117 \pm 14$ & $119 \pm 13$ & $117 \pm 15$ & n.s \\
Nighttime MAP $(\mathrm{mmHg})$ & $92 \pm 12$ & $102 \pm 12$ & $112 \pm 19$ & $<0.001$ \\
Dipping (\%) & $21 \pm 4$ & $14 \pm 2$ & $5 \pm 7$ & $<0.001$ \\
Daytime HR (beats/min) & $81 \pm 13$ & $79 \pm 10$ & $80 \pm 15$ & n.s. \\
Nighttime HR (beats/min) & $67 \pm 12$ & $66 \pm 8$ & $67 \pm 11$ & n.s \\
sWML (mm 3) & $1337 \pm 3106$ & $1861 \pm 5588$ & $806 \pm 1811$ & n.s. \\
pWML. [incidence, (\%)] & 43 & 31 & 26 & 0.037 \\
pWML (score) & $1.7 \pm 1.7$ & $1.5 \pm 2.2$ & $1.2 \pm 1.7$ & n.s. \\
Lacunar infactions (\%) & 45 & 33 & 22 & 0.048 \\
\hline
\end{tabular}

$\because$ one-way ANOVA; n.s., indicates not statistically different; MAP, indicates mean arterial pressure; HR, indicates heart rate; $s$, indicates subcortical; $p$, indicates periventricular; WML, indicates white matter lesions.

\section{Discussion}

The present study shows that periventricular but not subcortical WML are related to 24-hour blood pressure variability. Patients with essential hypertension who have a large nocturnal fall in pressure apparently tend to have pWML more often than patients in whom the blood pressure dip during sleep is small or absent. With respect to SWML no clear relationship with blood pressure emerges. Silent lacunar infarctions, on the other hand, are again more frequently found in patients with larger falls in pressure during the night.

Results of previous studies concerning the prevalence of WML in patients with hypertension are conflicting. This may be related, at least in part, to differences in patient selection and MRI scoring systems. ${ }^{15}$ As pointed out by Sierra and associates $^{6}$, most studies have been performed in elderly people or populations 
with a wide age range. When these investigators examined a group of 66 untreated patients with essential hypertension who were between 50 and 60 years of age, they found a high prevalence of WML (just as we did). In addition, they showed that the severity of hypertension and not the circadian pattern of nocturnal blood pressure fall determined the presence of these lesions. The latter is in contrast to our present findings. Of course, the difference between these two studies could be related to the wider age range in our patient population. However, this is unlikely to be the sole explanation, not the least because the average age in our study was comparable to that in the patient group of Sierra et al. Also, the fact that patients had never been treated in the Sierra study, while they were temporarily off treatment in ours, cannot fully account for the observed differences. There is, however, one fundamental difference between the two studies. Sierra and coworkers divided their patients on the basis of the presence of lesions in the brain and then compared the groups with and without WML for various clinical, biochemical and blood pressure characteristics. This is, in fact, a retrospective approach of the data. In our study, we have taken blood pressure as the discriminating factor to divide patients. In other words, by departing from the blood pressure profile we tried to 'prospectively' assess the impact of pressure on the prevalence of WML. In doing so, we identified the relationship between the nocturnal BP dip and the prevalence of $\mathrm{pWML}$. Because the score of pWML was not significantly different across the tertiles of BP dip (even though there was a trend), it seems possible that dividing patients simply on the basis of presence or absence of lesions may obscure the effect of BP.

It remains speculative why a larger nocturnal BP decline is associated with a greater prevalence of WML. Interestingly, the prevalence of silent lacunar infarctions was also higher when nocturnal BP was lower. Maintained, or even exaggerated, falls in nocturnal blood pressure were also observed in patients with lacunar infarctions as recently described by Boreas (Thesis, University of Maastricht, 2001). There are at least two possible explanations for these findings. The first is that the presence of WML or lacunar infarcts causes greater day-to-night variability of blood pressure. Although there are no data in the literature to support or reject this hypothesis, we cannot a priori exclude this possibility. However, a second, and perhaps more intriguing explanation could be that patients with reduced nocturnal dipping are relatively protected against the deleterious effects of an elevated pressure. One could hypothesize that larger shifs in pressure throughout a 24-hour period put a greater burden on autoregulatory systems in the brain, which may then decompensate at a faster pace than in patients in whom such shifts are smaller. Impairment of autoregulation of periventricular vessels with increasing age and hypertension, alone or combined, makes the brain more susceptible for hypoxia and could explain the observed relationship. Since both WML and lacunar infarcts are thought to have a microcirculatory origin, this possibility needs further attention. However, even then it remains elusive why we failed to show an association between BP and the prevalence of subcortical WML. 
$46 \mid$ Chapter 4

In conclusion, our data in an untreated uncomplicated hypertensive population show a relationship between nocturnal blood pressure decline and degree of WML in the periventricular area of the brain. 


\section{References}

1. Pantoni, L. and J.H. Garcia, The significance of cerebral white matter abnormalities 100 years after Binswanger's report. A review. Stroke, 1995. 26: 1293-1301.

2. van Swieten, J.C., et al., Hypertension in the elderly is associated with white matter lesions and cognifive decline. Ann Neurol, 1991. 30: 825-830.

3. Breteler, M.M., et al., Cerebral white matter lesions, vascular risk factors, and cognifive function in a population-based study: the Rotterdam Study. Neurology, 1994. 44: 1246-1252.

4. Longstreth, W.T., Jr., et al., Clinical correlates of white matter findings on cranial magnetic resonance imaging of 3301 elderly people. The Cardiovascular Health Study. Stroke, 1996. 27: 1274-1282.

5. Shimada, K., et al., Silent cerebrovascular disease in the elderly. Correlation with ambulatory pressure. Hypertension, 1990. 16: 692-699.

6. Sierra, C., et al., Silent cerebral white matter lesions in middle-aged essential hypertensive patients. J Hypertens, 2002 20: 519-524.

7. Fukuda, $H$. and M. Kitani, Differences between treated and untreated hypertensive subjects in the extent of periventricular hyperintensities observed on brain MRI. Stroke, 1995. 26: 1593-1597.

8. Liao, D., et al., Presence and severity of cerebral white matter lesions and hypertension, its treatment, and its control. The ARIC Study. Atherosclerosis Risk in Communities Study. Stroke, 1996. 27: 2262-2270.

9. Shimada, K., et al., Diurnal blood pressure variations and silent cerebrovascular damage in elderly patients with hypertension. J Hypertens, 1992. 10: 875-878.

10. Kario, K., et al., Nocturnal fall of blood pressure and silent cerebrovascular damage in elderly hypertensive patients. Advanced silent cerebrovascular damage in extreme dippers. Hypertension, 1996. 27: 130-135.

11. Kario, K., et al., Stroke prognosis and abnormal nocturnal blood pressure falls in older hypertensives. Hypertension, 2001. 38: 852-857.

12. Achten, E., et al., Rating scale for age related brain changes. Imaging decisions MRI, 2000. 1: 10-19.

13. Gronenschild, E., Brain Image Analysis System (BIAS). 2001, Maastricht University: Maastricht.

14. Bartko, J.J. and W.T. Carpenter, On the methods and theory of reliability. Journal of Nervous and Mental Disease, 1975. 163: 307-317.

15. Kivipelto, M., H. Soininen, and J. Tuomilehto, Hypertension and white matter lesions of the brain. J Hypertens, 2002. 20: 387-389. 


\section{Chapter 5}

Is there a side predilection for cerebrovascular disease?

Rodriguez Hernández SA, Kroon AA van Boxtel MPJ, Mess WH, Lodder J, Jolles J, de Leeuw PW 


\section{Abstract}

\section{Background}

In studies on carotid artery intima media thickness (IMT) and stroke, researchers implicitly assume that cerebrovascular abnormalities show a symmetrical distribution.

\section{Methods and results}

To evaluate whether there is a difference in IMT between the two carotids we compared left and right common carotid artery IMT meosured by B-mode ultrasonography in a group of 102 untreated hypertensive patients. The average IMT showed a significant difference between both sides (left: $0.75 \pm 0.11 \mathrm{~mm}$; right $0.71 \pm 0.11 \mathrm{~mm} ; p<0.001$ ). This was associated with a higher cross sectional area of IMT and a higher flow velocity at the left side. Arterial diameters, however, were not different. Because a higher IMT may be associated with an increased risk of non-lacunar stroke, we also assessed whether there is a side preference with respect to cerebrovascular accidents. To this end, we explored our population-based Stroke Registry of 1843 subjects and, indeed, found a significantly higher incidence of non-lacunar cerebrovascular stroke at the left side, while lacunar infarcts were symmetrically distributed.

\section{Conclusion}

Our findings suggest a predilection for cerebrovascular disease at the left side, which may be related to greater intimal damage in the left carotid artery. 


\section{Introduction}

An increase in carotid artery intima media thickness (IMT) not only coincides with other risk factors such as hypercholesterolemia, hypertension and diabetes mellitus, but also correlates independently with clinical endpoints such as myocardial infarction and peripheral atherosclerosis. ${ }^{1.7}$ Recent data have confirmed the relationship between IMT and stroke, especially of the nonlacunar subtype. ${ }^{8}$ Thus, an increase in IMT can be considered as a marker of cardiovascular risk. Usually, one average measurement from the left and right common carotid artery for the determination of IMT. ${ }^{9}$ However, it is not known whether this is justified, as differences may exist in IMT between both arteries. Indeed, during routine assessment we frequently noted a left-right difference in IMT. Other studies also suggest differences between left and right $\mathrm{IMT}^{5.9}$, but it is not clear whether there is a systematic difference in favour of one side. The present study was performed to investigate this possibility in more detail. In the first part we systematically compared left and right IMT in a group of hypertensive patients who had been referred to our hospital for evaluation of their elevated blood pressure. The second part comprised a retrospective analysis of the Maastricht Stroke Registry, which contains data on all stroke patients admitted to our hospital since 1988. This was done to assess whether there is a side preference in the occurrence of non-lacunar stroke. We hypothesised that atherosclerotic complications as they relate to an increased IMT may progress at a faster pace in the thickest carotid artery and, hence, that hemispheric infarcts may occur more often at that side of the brain.

\section{Subjects and Methods}

\section{Study 1: IMT measurements}

Patients were selected from the hypertension outpatient clinic of the Department of Internal Medicine of the University Hospital of Maastricht. As part of the local protocol IMT measurements were performed in all patients. For the present analysis we selected 102 untreated hypertensive patients in whom no known cause for their hypertension could be detected and who were without apparent cardiovascular complications. This specific population was chosen because hypertension is a major determinant of IMT and stroke ${ }^{10,11}$ and because the absence of cardiovascular complications would render secondary changes of IMT less likely. Blood pressure was measured before each IMT measurement after 5 minutes of rest in sitting position. Measurements of the IMT of the posterior wall as well as of lumen diameters of the left and right common carotid artery were obtained $1 \mathrm{~cm}$ proximal to the bulb from an anterolateral 
and posterolateral view (SONOS 5500; Agilent-Philips; linear array transducer, 3.11 $\mathrm{MHz}$ ). The left and right artery were investigated in random order.

End diastolic B-mode images of the IMT were analysed offline with an automated edge-tracking method (M'ath, version 2.0.1; Metris, France). ${ }^{12}$ The average IMT was measured over a length of $10 \mathrm{~mm}$, and the mean of both the anterolateral and posterolateral view at each side was calculated and used for further analyses. In addition flow velocity indices, i.e. mean velocity $(\mathrm{cm} / \mathrm{sec})$, pulsatility index $(\mathrm{PI})$ and resistance index $(\mathrm{RI})$, were derived from the Doppler spectrum. $\mathrm{PI}$ and $\mathrm{RI}$ were calculated as follows: $\mathrm{PI}=(\mathrm{S}-\mathrm{D}) / \mathrm{MN}$ and $\mathrm{RI}=(\mathrm{S}-\mathrm{D}) / \mathrm{S}$, in which $S$ and $D$ indicate systolic and diastolic velocity $(\mathrm{cm} / \mathrm{sec})$, respectively, and $M N$ mean velocity $(\mathrm{cm} / \mathrm{sec})$. The cross sectional area of IMT (CSA-IMT) was calculated according to the formula: CSA-IMT $=\times$ IMT $\times(I M T+D)$, in which D is lumen diameter $(\mathrm{mm}))^{9}$ Measurements were performed by four trained operators, none of whom was aware of the purpose of the study. Although patients were informed why they were investigated, they did not know that this comprised evaluation of a left-right difference in IMT.

\section{Study 2: Stoke registry}

The Maastricht Stroke Registry is a large database containing prospectively entered clinical, neuroradiological and outcome data of all patients that have been admitted to our hospital with a stroke. ${ }^{10}$ The University Hospital is the only hospital in the Maastricht region and has an adherent population of approximately 200.000 people. The Registry started in 1988 and at the time of this study had data on 1843 patients. We explored the Registry and compared the frequency of territorial large vessel atherosclerotic cerebral infarcts and cardioembolic stroke in both hemispheres. In addition, we looked at side differences for small deep lacunar infarcts. This type of infarct would not be expected to occur more frequently on one side, because it is generally caused by local, intra-cerebral small vessel disease.

A territorial infarct was defined as an acute stroke syndrome with CT or MRI findings compatible with infarction involving the cortex, or in the absence of a specific lesion, as a clinically identified cortical syndrome consisting of unilateral motor and/or sensory symptoms and signs in combination with signs of cortical dysfunction with or without visual field defect, or as isolated monoparesis or as isolated cortical dysfunction (usually dysphasia). Patients with a large subcortical infarct were included in the territorial infarct group because of similar pathogenesis. Territorial infarct patients with a potential cardioembolic stroke source were assigned to the cardioembolic stroke subgroup. Such patients had at least one of the following cardiac features: chronic or intermittent ECG confirmed atrial fibrillation; left ventricular myocardial infarction within six weeks preceding stroke; left ventricular or atrial thrombus; left ventricular aneurysm; left ventricular akinetic segment; cardiomyopathy; mitral or aortic valve abnormalities (endocarditis, mitral stenosis, prosthetic aortic or mitral valves); and in young patients without any other specific stroke cause: atrial septal defect, ventricular septal defect. Patients with a non-cardioembolic symptomatic territorial infarct (presumably large vessel disease, i.e. atherothrombosis or 
artery-to-artery embolism whether or not confirmed by non-invasive carotid studies) were assigned to the atherothrombotic infarct subgroup. A lacunar infarct (LACI) was defined as an acute stroke syndrome with a CT or MRI lesion compatible with occlusion of a single perforating artery, i.e., a small, subcortical, sharply marginated hypo-dense (CT) or hyper-intense (MRI) lesion with a diameter smaller than $15 \mathrm{~mm}$ (small deep infarct), or as a specific lacunar syndrome (i.e., unilateral motor and/or sensory symptoms and signs that completely involved at least 2 of 3 body parts (face, arm, leg) without disturbance of consciousness or language, visual field defect, or other signs of cortical dysfunction) in the absence of a specific lesion on neuroimaging. A potential cardioembolic stroke cause was not taken into account when assigning patients to this infarct subgroup. Patients with a 'rare' stroke cause, such as arterial dissection, vasculitis, fibromuscular dysplasio, hematological disorder, etc. were not included in the study because of small numbers and heterogeneity in stroke cause.

The study was approved by the Medical Ethical Committee of the Maastricht University Hospital, and performed according to the institutional guidelines. All subjects, or, if necessary, the next of kin gave written informed consent to use patient data for this type of scientific evaluation.

\section{Statistical analysis}

Differences in IMT between the left and right carotid were determined using ttests for paired samples. The concordance between left and right IMT was analysed by linear regression. Bland-Altman analysis was used to assess systematic differences between both sides. ${ }^{13}$ Proportional differences between stroke subgroups were determined using Chi-tests. Data are shown as mean \pm standard deviation (SD), unless indicated otherwise. A p-value less than 0.05 was considered statistically significant.

\section{Results}

\section{Study 1}

Mean age of the 102 hypertensive subjects was $56 \pm 11$ years, $60 \%$ were male, and body mass index averaged $29 \pm 6 \mathrm{~kg} \cdot \mathrm{m}^{-2}$. Office systolic and diastolic blood pressures were $165 \pm 7$ and $94 \pm 8 \mathrm{mmHg}$, respectively. A close relationship was found between the IMT of both sides (regression equation $y=0.5755 x+0.2844$; $R^{2}=0.4528 ; p<0.001$; Figure 5.1). Table 5.1 shows the IMT of the left and right carotid artery: $0.75 \pm 0.11 \mathrm{~mm}$ and $0.71 \pm 0.11 \mathrm{~mm}$, respectively; $p<0.001$. The mean left-right difference was $0.03 \pm 0.09 \mathrm{~mm}$ with no systematic deviation at any level of average IMT (Figure 5.2). There was no significant difference in luminal diameter between both carotids (Table 5.1). Differences in IMT between the left and right side remained significant after correction for the diameter. As 
54 Chapter 5

shown in Table 5.1 the cross-sectional area of the intima-media complex was greater at the left side as well. Mean blood flow velocities in the left and right carotid artery at the side where the IMT measurements were performed were $41.1 \pm 9.4 \mathrm{~cm} / \mathrm{sec}$ versus $39.3 \pm 9.8 \mathrm{~cm} / \mathrm{sec}$, respectively $(p=0.004)$. No differences between left and right arteries could be found with respect to $\mathrm{PI}$ and RI (Table 5.1).

Results were similar for all four observers.

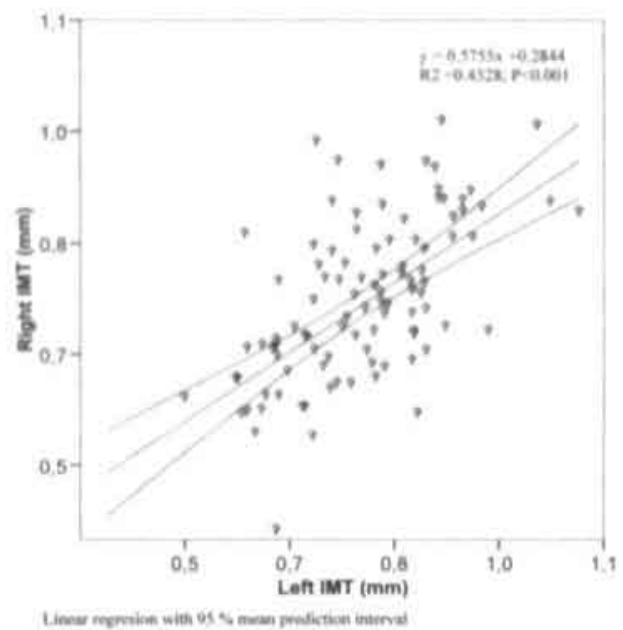

Figure 5.1. Left versus right sided carotid intima-media thickness (IMT), $n=102$ (regression line and $95 \%$ meon confidence interval).

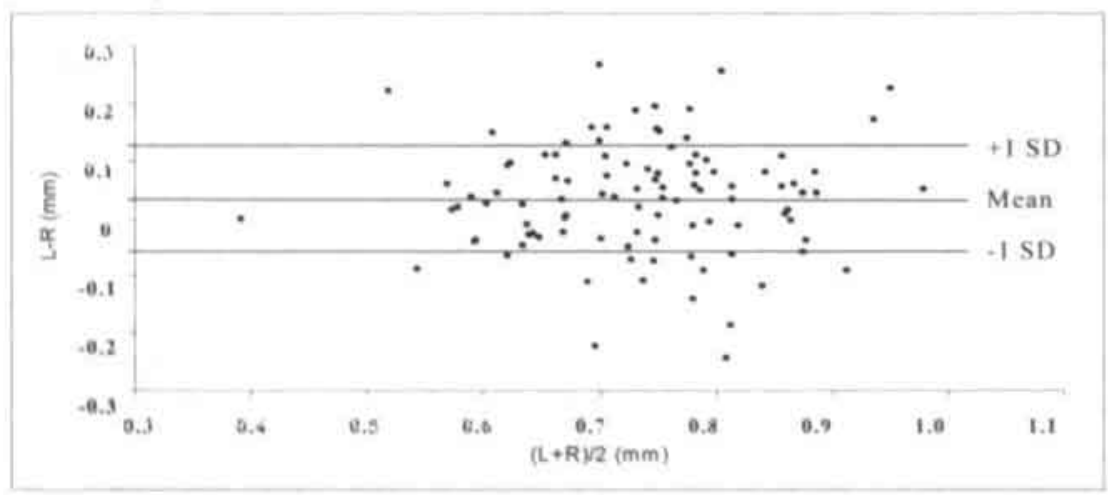

Figure 5.2. Bland Altman plot of the difference between left $(L)$ and right $(R)$ intima media thickness as a function of their means $(n=102)$. 
Side predilection for cerebrovascular disease

Table 5.1. Echo Doppler characteristics of left and right common carotid artery

\begin{tabular}{lccc}
\hline & Left & Right & p value \\
\hline IMT $(\mathrm{mm})^{+}$ & $0.75 \pm 0.11$ & $0.71 \pm 0.11$ & $<0.001^{*}$ \\
Lumen $(\mathrm{mm})$ & $7.5 \pm 1.0$ & $7.6 \pm 1.0$ & n.s. \\
PI ${ }^{*}$ & $1.18 \pm 0.39$ & $1.19 \pm 0.40$ & n.s. \\
RI $^{\text {s }}$ & $0.64 \pm 0.09$ & $0.64 \pm 0.10$ & n.s. \\
Mean velocity $(\mathrm{cm} / \mathrm{sec})$ & $41.1 \pm 9.4$ & $39.3 \pm 9.8$ & $0.004^{*}$ \\
CSA-IMT $\left(\mathrm{mm}^{3}\right)$ & $10.6 \pm 3.0$ & $9.9 \pm 2.7$ & $0.001^{*}$ \\
\hline
\end{tabular}

- -test for paired samples; ${ }^{\dagger}$ intima media thickness; ${ }^{2}$ pulsatility index; ' resistance index;

"I not significantly different.

\section{Study 2}

The median age of the patients $(n=1843)$ in this database was 72 years (range $25-99$ ), $51 \%$ was male and $50 \%$ was known with hypertension (systolic blood pressure $.160 \mathrm{mmHg}$ and/or diastolic blood pressure $.90 \mathrm{mmHg}$ ). Lacunar infarcts appeored to be symmetrically distributed (Table 5.2). In contrast, for non-lacunar strokes we found a predilection for side: both atherosclerotic and cardioembolic stroke subtypes were significantly more frequent in the left hemisphere: Chi=9.81, OR 1.39 (95\% Cl 1.13-1.70), and Chi=7.49, OR 1.46 (95\% Cl 1.11-1.92), respectively (Table 5.2). Stroke severity, based on the Rankin score, was not different for left-sided and right-sided strokes.

Table 5.2. Distribution of stroke subtypes in the Maastricht Stroke Registry

\begin{tabular}{lccc}
\hline Subtypes & Number & Left $(\%)$ & Right $(\%)$ \\
\hline Lacunar & 721 & $357(49.9)$ & $364(50.1)$ \\
Cardioembolic & 319 & $188(58.9)^{*}$ & $131(41.1)$ \\
Atherosclerotic & 803 & $463(57.7)^{\circ}$ & $340(42.3)$ \\
All strokes & 1843 & $1008(54.7)$ & $835(45.3)$ \\
\hline
\end{tabular}

- $p<0.001$ for left/right difference

\section{Discussion}

The present study shows that in untreated essential hypertensives a difference exists between IMT of the left and right carotid artery, with higher values on the left side. Also, cross-sectional area (a marker of vascular mass) of the intimamedia complex was larger on the left then on the right side. In most published studies IMT values are seldomly reported for the left and right carotid separately. However, in studies in which data are actually given for both sides, the IMT of the left common carotid tends, on average, to be larger than on the right. ${ }^{9.15}$ Although the clinical significance of this asymmetry is not yet apparent, it has been shown recently that a thicker intima-media complex is associated with non- 
lacunar strokes. ${ }^{8}$ Accordingly, we hypothesized that if the left-right differences in IMT were to be a general phenomenon, one could expect a side preference for the occurrence of non-lacunar stroke as well. This was, indeed, borne out by the anatomical predilection of non-lacunar strokes in the left hemisphere in our Stroke Registry. Non-lacunar strokes can be divided in atherosclerotic and cardioembolic subtypes. Generally, lacunar strokes are caused by local obstruction, and not by embolism, whereas most cardioembolic strokes occur in the absence of carotid disease.

Therefore, the similarity between cardioembolic and atherosclerotic strokes with regard to predilection to the left hemisphere in our study suggests a role for hemodynamic factors. These may cause more cardiac emboli to enter the left carotid system, and also more often affect the left carotid artery structure. Since we also observed a significant difference in mean flow velocity between the two carotids, hemodynamic factors may, indeed, contribute to differences in vascular pathology. Our data suggest that shear forces, which are strong determinants of adaptive intima media thickening, are different in both arteries and that the left and right carotid are exposed differentially to the early atherosclerotic process. The fact that it takes longer for the blood to flow through the oortic arch could also play a role as atherosclerotic lesions at this side may cause embolic stroke. ${ }^{14}$

To the best of our knowledge, no data have been published with regard to side predilection of strokes. Even though we compared stroke rates in a different population than the one in which we obtained IMT measurements, our data are in accordance with the assumption that atherosclerotic lesions develop earlier on the left side.

One could argue that the differences in the site of strokes may have resulted from admission bias in this particular cohort of patients: left hemispheric infarcts may be more symptomatic, and rated by physicians as more severe. However, the initial stroke severity in our Registry was similar between left and right hemispheric infarcts, which makes such a bias less likely.

In conclusion, we have shown an increased IMT at the left side and suggest that this may predispose to a higher prevalence of left hemispheric non-lacunar infarcts. Further prospective studies investigating the relationship of IMT and stroke in the same cohort are necessary to provide support for these results and warrant reporting data from both left and right carotid arteries when performing IMT measurements. Our findings may set the stage for an early, differential preventive strategy for left or right carotid artery disease. This may be highly relevant as the left hemisphere is dominant in most people. 


\section{References}

1. Heiss G, Sharrett AR, Barnes R, et al. Carotid atherosclerosis measured by B-mode ultrasound in populations: associations with cardiovascular risk factors in the ARIC study. Am J Epidemiol 1991;134:250-256

2. Gariepy J, Simon A, Massonneau M, et al. Wall thickening of carotid and femoral arteries in male subjects with isolated hypercholesterolemia. PCVMETRA Group. Prevention Cardio-Vasculaire en Medecine du Travail. Atherosclerosis 1995;113: 141-151

3. Folsom AR, Eckfeldt JH, Weitzman S, et al. Relation of carotid artery wall thickness to diabetes mellitus, fasting glucose and insulin, body size, and physical octivity. Atherosclerosis Risk in Communities (ARIC) Study Investigators. Stroke 1994;25:66. 73

4. Zannad F, Visvikis S, Gueguen R, et al. Genetics strongly determines the wall thickness of the left and right carotid arteries. Hum Genet 1998;103:183-188

5. Salonen JT, Solonen R. Ultrasound B-mode imaging in observational studies of atherosclerotic progression. Circulation 1993;87(3 S1):1156-65

6. Iannuzzi A, Wilcosky T, Mercuri M, et al. Ultrasonographic correlates of carotid atherosclerosis in transient ischemic attack and stroke. Stroke 1995;26:614-619

7. Cuspidi $C$, Lonati L, Sampieri L, et al. Left ventricular concentric remodelling and carotid structural changes in essential hypertension. J Hypertens 1996;14:14411446

8. Cupini LM, Pasqualetti P, Diomedi M, et al. Carotid artery intima-media thickness and lacunar versus nonlacunar infarcts. Stroke, 2002;33:689-694.

9. Simon A, Gariepy J, Chironi G, et al. Intima-media thickness: a new tool for diagnosis and treatment of cardiovascular risk. J Hypertens 2002;20:159-169

10. Boreas AM, Lodder J, Kessels F, et al. Prognostic value of blood pressure in acute stroke. J Hum Hypertens 2002;16:111-116.

11. Mancia G, Parati G, Hennig M, et al. Relation between blood pressure variability and carotid artery damage in hypertension: baseline data from the European Lacidipine Study on Atherosclerosis (ELSA). J Hypertens, 2001;19:1981-1989.

12. Graf S, Gariepy J, Massonneau M, et al. Experimental and clinical validation of arterial diameter waveform and intimal media thickness obtained from B-mode ultrasound image processing. Ultrasound Med Biol 1999. 25:1353-1363.

13. Bland JM, Altman DG. Comparing methods of measurement: why plotting difference against standard method is misleading. Lancet 1995;346:1085-1087.

14. Amarenco P, Duyckaerts $C$, Tzourio $C$, et al. The prevalence of ulcerated plaques in the aortic arch in patients with stroke. N Engl J Med 1992;326:221-225

15. Lemne $C$, Jogestrand $T$, de Faire U. Carotid intima-media thickness and plaque in borderline hypertension. Stroke 1995;26:34-39 



\section{Chapter 6}

Effect of polymorphisms of the angiotensinconverting enzyme and apolipoprotein E on carotid intima-media thickness in untreated hypertensives 


\section{Abstract}

\section{Background}

Several studies hove assessed the relationship between intima-medio thickness (IMT) and the angiotensin-converting enzyme (ACE) insertion/deletion (I/D) polymorphism and/or the apolipoprotein (Apo) E polymorphism. Interaction between several polymorphisms is thought to be more important than the effect of a single gene. Recently, it has been suggested that asymmetry in carotid IMT is present.

\section{Objective}

To investigate the individual effects of the aforementioned polymorphisms and their interaction on the common carotid artery IMT at both left and right side, in hypertensive patients at risk for development of carotid artery atherosclerosis.

\section{Methods}

This cross-sectional study incorporated 109 untreated, hypertensive subjects, in which IMT of the common carotid artery was assessed ultrasonographically (B-mode). To correct for differences in lumen diameter the cross-sectional area of the IMT was calculated. Left-toright differences of the IMT was assessed and related to the individual and interactive effects of the ACE D allele and the Apo E4 allele.

\section{Results}

A significant association of the ACE D allele was found with the mean IMT of both sides, and, left or right carotid IMT separately, Left carotid IMT was significantly thicker than right. For both sides the D allele showed a gene-dose effect. The Apo E polymorphism did not influence IMT, alone or in the presence of an ACE D allele.

\section{Conclusion}

The ACE D allele is a determinant of the IMT of the common carotid artery in hypertensive subjects. There is no synergy with the Apo E4/* genotype. Significant differences in IMT between the left and right carotid artery are present, which may be relevant for side predilection of stroke. 


\section{Introduction}

An increase in carotid artery intima-media thickness (IMT) not only coincides with other risk factors like hypercholesterolemia, hypertension and diabetes mellitus, but also correlates independently with clinical endpoints such as myocardial infarction, stroke and peripheral atherosclerosis. ${ }^{1-8}$ Measurements of carotid artery IMT, and probably also of femoral artery IMT ${ }^{10}$ are generally considered, therefore, to provide information about the risk of future atherosclerotic complications. "

The mechanisms leading to increased IMT are not well understood but may involve genetic factors. Among the latter polymorphisms in the angiotensinconverting enzyme (ACE) gene and the gene encoding for apolipoprotein (Apo) $\mathrm{E}$ rank high. Several studies have addressed the association between these candidate genes and the carotid IMT, but mostly with conflicting results. ${ }^{72-23}$ As far as the association between atherosclerotic complications and the insertion/delefion (I/D) polymorphism of the ACE gene is concerned, recently performed meta-analyses remained inconclusive. ${ }^{24.25}$ Even though the presence of the ACE D allele seem to be associated with atherosclerotic complications, this is not true for all populations. The Apo E gene has 3 common alleles, APO*E2, APO*E3, and APO*E4. ${ }^{26}$ Apo E plays a pivotal role in the transport of lipoproteins and is involved in numerous processes in the arterial wall. ${ }^{27,28}$ Studies on this gene indicated that either the presence of the E4 or the E2 allele are associated with an increased carotid IMT. ${ }^{29}$ However, it has been suggested that the E2 allele may have a protective effect with regard to morbidity and mortality of atherosclerosis ${ }^{30,31}$, and that an excess of subjects with one or two apo E4 alleles is found among populations with high cardiovascular risk. ${ }^{18,32}$

Evidence is accumulating that analyses of additive effects and/or synergism between candidate genes, especially in the presence of the ACE D allele, are more important than single-gene studies. ${ }^{10,33,34}$ The relationship between carotid IMT and the ACE I/D and/or Apo E polymorphisms has been assessed in only a few studies ${ }^{7.20}$, but the combined effect of these risk alleles has not been investigated.

Therefore, the aim of the present study was to investigate the interaction of the ACE I/D and Apo E polymorphisms on the carotid IMT in a group of untreated hypertensive subjects. Since we recently found that there is a difference in left and right carotid artery IMT in such patients, we also examined whether this difference is genotype-dependent. 


\section{Methods}

\section{Study population}

Participants were selected from the hypertension outpatient clinic of the Department of Internal Medicine of the University Hospital of Maastricht. As part of the local protocol, IMT measurements were performed in all patients. For the present analysis we selected 109 hypertensive patients who were between 40 and 80 years of age, in whom no known cause of their hypertension could be detected, and who were without apparent cardiovascular complications. This specific population was chosen because hypertension is a major determinant of IMT and stroke and because the absence of cardiovascular complications would render secondary changes of IMT less likely. ${ }^{35,36}$ Exclusion criteria were clinically documented ischemic or valvular heart disease, congestive heart failure, cerebrovascular accidents and/or transient ischemic attacks, chronic renal failure, or secondary hypertension. None of the participants were members of the same family. In all patients antihypertensive medication was discontinued for tree weeks prior to the measurements. None of the subjects developed adverse events during this drug-free period, and all participants gave their informed

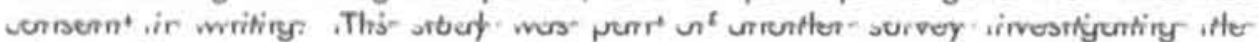
relationship between neuropsychological function tests and hypertensioninduced target organ damage of the brain. The study was approved by the local medical ethics committee.

\section{Blood Pressure Measurements and other covariates}

Noninvasive ambulatory blood pressure measurements (Spacelabs 92127, Redmond, WA) were obtained starting on a morning weekday. The cuff was applied to the non-dominant arm. For analysis, daytime was defined from 7:00 a.m. till 11:00 p.m. and nighttime from 1:00 a.m. till 6:00 a.m. The apparatus was programmed to perform blood pressure measurements every 15 minutes during the day and every 30 minutes during the night. Subjects were instructed to adhere to their normal daily activities and regular sleeping hours. Office blood pressure was measured by means of a random zero sphygmomanometer on both arms in sitting position during the visit.

The body mass index (BMI) was calculated as weight divided by height square. Information on risk factors like smoking was obtained with a standardized questionnaire, which was checked by a physician during the interview.

\section{Carotid artery intima-media thickness}

Ultrasound measurements were performed in all patients in the recumbent position. Measurements of the IMT of the posterior wall of the left and right common carotid artery were obtained $1 \mathrm{~cm}$ proximal to the bulb from an anterolateral and posterolateral view (SONOS 5500; Agilent-Philips; linear array transducer, 3-11 $\mathrm{MHz}$ ). The left and right arteries were investigated in random order. Enddiastolic B-mode images of the IMT were analyzed offline 
with an automated edge-tracking method (M'ath, version 2.0.1; Metris, France). ${ }^{37}$ Offline, the frame showing the narrowest diameter in the enddiastolic phase was selected and stored as a bitmop file for further processing. The average IMT was measured over a length of $10 \mathrm{~mm}$, and the mean of both the anterolateral and posterolateral view at each side was calculated and used for further analysis. To correct the IMT for differences in lumen diameter the cross sectional area of IMT (CSA-IMT) was calculated according to the formula: CSA$I M T=\pi \times I M T \times(I M T+D)$, in which $D$ is the lumen diameter $(\mathrm{mm}) . " 1$ Measurements were performed by four trained operators, none of who was aware of the purpose of the study. Although patients were informed why they were investigated, they did not know that this also comprised evaluation of a left-right difference in IMT.

\section{Genetics}

The ACE I/D and the apo E polymorphisms were determined at the Cardiovascular Genotyping (CAGT) laboratory of the Department of Internal Medicine of the University Hospital Maastricht. DNA was extracted from whole blood using the QIAamp" Blood Kit (Qiagen Inc., Valencia, CA). ${ }^{38}$ Genotyping was performed using a multilocus genotyping assay for candidate markers of cardiovascular disease risk (Roche Molecular Systems Inc., Alameda, CA). Briefly, each DNA sample is amplified using two multiplex polymerase chain reactions, and the alleles are genotyped simultaneously using an array of immobilized, sequence-specific oligonucleotide probes. This array of probes is blotted on plastic strips and after staining genotypes can be scored based on blue (positive) and white (negative) bands. Each blue band, representing a specific genotype, was scored by specific software (counting the pixel intensity of each band) and manually checked.

\section{Statistical Analysis}

The data pertaining to the cases were uploaded into a commercially available spreadsheet, and this was in turn uploaded into a statistical program (SPSS Inc., Chicago, Illinois, USA). Differences in IMT between the left and right carotid artery were determined using the $t$-test for paired samples. Differences between genotype groups were tested by analysis of variance (one-way ANOVA), using Bonferroni's method for post hoc multiple comparisons between genotype classes. Genotype frequencies between groups were compared using a Chi-test and tests for Hardy-Weinberg equilibrium were carried out using standard methods. The interaction between the ACE and the apo E polymorphisms on IMT was tested using the following model: IMT $=b_{0}+b_{1} X+b_{2} Y+b_{3} X Y$, in which $b$ represents a constant variable, $X$ the risk allele of polymorphism $X, Y$ the risk allele of polymorphism $Y$, and $X Y$ the interaction between the two. The mean coding approach was also used to test for interaction ${ }^{39}$. The latter method was added because it does not imply any genetic hypothesis.

Based on literature, we decided to perform the primary analyses with regard to the Apo $E$ polymorphism on subjects with one or two Apo E4 alleles (Apo E4/*) versus 
the remaining subjects, which were those with the Apo E3/3, E3/2 and E2/2 combinations, the Apo $\mathrm{E} 4 /^{*}$ group being the one with increased risk of intimamedia thickening. Secondary analyses were done in two other groups: Apo E3 or E2 / E3 or E2 versus the remaining combinations, in which the Apo E3-2/E3-2 subjects are supposed to be those with the lowest cardiovascular risk.

All data are presented as mean \pm standard deviation (SD), unless indicated otherwise. A p-value less than 0.05 was considered statistically significant.

\section{Results}

The mean age of the 109 subjects was $56 \pm 11$ years, $60 \%$ were male, body mass index averaged $29 \pm 6 \mathrm{~kg} / \mathrm{m}^{2}$, and $46 \%$ were current smokers. Office systolic and diastolic blood pressures off treatment were $165 \pm 7$ and $94 \pm 8$ $\mathrm{mmHg}$, respectively, and mean $24 \mathrm{~h}$ ambulatory measurements $152 \pm 20$ and $93 \pm 12 \mathrm{mmHg}$, respectively.

The genotype distributions of both the ACE I/D and the Apo E polymorphisms were in Hardy-Weinberg equilibrium. Results of the IMT measurements are shown in Table 6.1. The mean IMT of all subjects was $0.73 \pm 0.10 \mathrm{~mm}$. A significant difference between the IMT of the left and right carotid artery was found: $0.75 \pm 0.11 \mathrm{~mm}$ and $0.71 \pm 0.11 \mathrm{~mm}$, respectively $(p<0.001)$. Lumen diameter was not significantly different for both carotids. Differences in IMT between the left and right side remained significant after calculation of the CSAIMT (Figure 6.1). Both subjects with the Apo E4/* and those with the Apo $E_{k} /{ }^{*}$ genotype had significantly thicker common carotid IMT at the left side in comparison to the right side (Table 6.1). However, no difference in either left or right CSA-IMT was observed between both genotype groups (Figure 6.1, panel A). In the presence of one or two ACE D alleles, left carotid IMT was also significantly thicker than the right one (Table 6.1). Moreover, a dose effect of the $D$ allele was observed in the left $(p=0.001)$ as well as in the right carotid artery $(p=0.03)$, not only for the uncorrected IMT but also for the CSA-IMT (Figure 6.1, panel B). In univariate analysis, the D allele was significantly associated with the mean carotid IMT $(p=0.04)$ and with the left carotid IMT $(p=0.03)$, but not with the IMT at the right side. Apo E allele groups were not associated in univariate analysis with any of the IMT values. This was true when alleles were grouped either as Apo E4/* or as Apo E3-2/E3-2.

Table 6.2 shows the IMT data in relation to both the ACE I/D and the Apo E alleles. Using the linear regression model, no evidence for interaction between the ACE and the Apo E gene was found. Since there is uncertainty with respect to the pattern of inheritance (recessive, co-dominant or dominant), we re-analyzed the data using the mean coding approach. This analysis showed a significant deviation from the population mean in the presence of two $D$ alleles of the mean carotid IMT $(p=0.05)$ and of the left carotid IMT $(p=0.03)$. This did not change significantly in the presence of an Apo E4 allele or E3-2 alleles. 
Table 6.1. Intima media thickness subdivided by Apo E and ACE I/D polymorphism.

\begin{tabular}{lcccc}
\hline & Left $(\mathrm{mm})$ & Right $(\mathrm{mm})$ & Mean & $p$-value \\
\hline All subjects & $0.75 \pm 0.12$ & $0.72 \pm 0.11$ & $0.73 \pm 0.10$ & $p=0.001$ \\
Apo E genotype & & & & \\
E4/* $(n=29)$ & $0.76 \pm 0.09$ & $0.71 \pm 0.11$ & $0.73 \pm 0.09$ & $p=0.004$ \\
ER' $(n=68)$ & $0.75 \pm 0.12$ & $0.72 \pm 0.12$ & $0.73 \pm 0.11$ & $p=0.031$ \\
ACE genotype & & & & \\
II $(n=23)$ & $0.67 \pm 0.13$ & $0.68 \pm 0.09$ & $0.68 \pm 0.10$ & $n . s$. \\
ID $(n=53)$ & $0.75 \pm 0.11$ & $0.71 \pm 0.11$ & $0.73 \pm 0.10$ & $p=0.007$ \\
$D D(n=33)$ & $0.78 \pm 0.11$ & $0.74 \pm 0.10$ & $0.76 \pm 0.09$ & $p=0.024$ \\
\hline
\end{tabular}

- paired $t$-test $t$-test left versus right $I M T ;{ }^{\circ} R$, indicates all remaining (non Apo $E 4 /{ }^{*}$ ) genotypes, i.e. Apo E3/E3, E3/E2, and E2/2.

Table 6.2. Intima media thickness in relation to both the ACE $1 / D$ and Apo E polymorphisms.

\begin{tabular}{lccc}
\hline & ACE I/D & \multicolumn{2}{c}{ Apoliprotein E } \\
\cline { 2 - 4 } & & Apo E4/* & Apo ER" \\
\hline Mean IMT & II & $0.79 \pm 0.05$ & $0.67 \pm 0.16$ \\
Left IMT (mm) & & $0.78 \pm 0.10$ & $0.68 \pm 0.17$ \\
Right IMT $(\mathrm{mm})$ & & $0.80 \pm 0.01$ & $0.67 \pm 0.18$ \\
\hline Mean IMT & \multirow{2}{*}{ ID } & $0.73 \pm 0.09$ & $0.73 \pm 0.10$ \\
Left IMT $(\mathrm{mm})$ & & $0.76 \pm 0.09$ & $0.74 \pm 0.11$ \\
Right IMT $(\mathrm{mm})$ & & $0.70 \pm 0.11$ & $0.71 \pm 0.11$ \\
\hline Mean IMT & \multirow{2}{*}{ DD } & $0.73 \pm 0.09$ & $0.77 \pm 0.09$ \\
Left IMT $(\mathrm{mm})$ & & $0.76 \pm 0.09$ & $0.79 \pm 0.11$ \\
Right IMT $(\mathrm{mm})$ & & $0.70 \pm 0.12$ & $0.75 \pm 0.09$ \\
\hline
\end{tabular}

' $R$, indicates all remaining (non Apo E4/*) genotypes, i.e. Apo E3/E3, E3/E2, E2/2. 
$66 \mid$ Chapter 6

\section{Panel a}

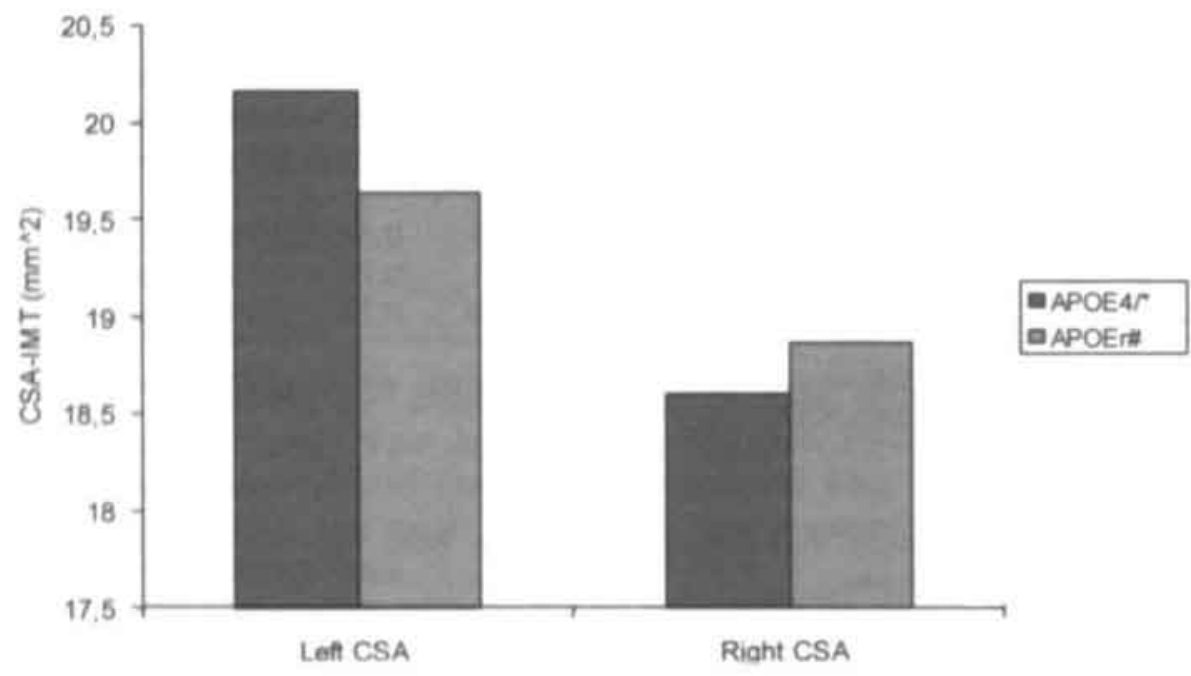

Panel b

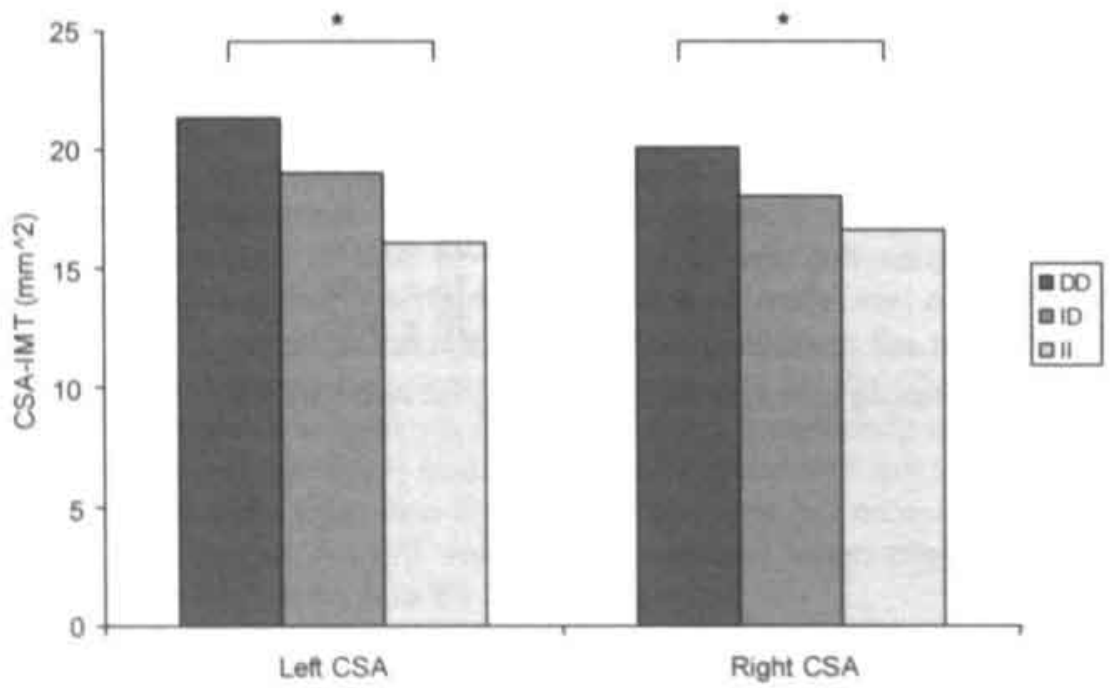

Figure 6.1. Cross sectional area of the intima-media thickness (CSA-IMT) of the left and right common carotid artery (CCA) in relation to the apolipoprotein (Apo) $E$ polymorphism (panel $A$ ) and the angiotensin-converting enzyme (ACE) insertion/deletion (I/D) polymorphism (panel B).

Apo $E_{\mathrm{R}}$ indicates all the remaining (non-Apo $E 4 / /^{*}$ ) polymorphisms, i.e. Apo $E 3 / E 3, E 3 / E 2$, and E2/E2. 


\section{Discussion}

In the present study we investigated the individual and interactive influences of two polymorphisms on the IMT of the common carotid artery of untreated hypertensive subjects. Our data show an association of the ACE D allele with the mean carotid IMT, and, left or right carotid IMT separately. The Apo E polymorphism did not influence IMT, either alone or in the presence of an ACE $D$ allele.

Several studies have reported on relationship between the ACE I/D polymorphism and carotid IMT. ${ }^{10}, 12,14,17,19.23$ From these, approximately half described a positive association between the ACE D allele and the carotid IMT, in a Japanese ${ }^{15}{ }^{17}$, Italian ${ }^{12}$, Chinese ${ }^{27}$, and Finish population ${ }^{16}$, respectively. Most of these studies were performed in healthy, middle-aged populations. Therefore, it is difficult to compare the results of these studies with ours. As a matter of fact, only one study is comparable to ours: Jeng et al. ${ }^{27}$ also observed a positive association with the presence of the ACE D allele in hypertensive, middle-aged subjects, who are at increased risk for development of carotid artery atherosclerotic pathology. Recently, Balkestein ef al. ${ }^{10}$ showed in the population-based FLEMENGHO study the same association with the D allele, however, only with regard to the femoral IMT and not the carotid artery IMT. Nevertheless, these data confirm that the presence of the ACE D allele is an important genotypic marker for the development of atherosclerosis. However, selection of the study population, e.g. with or without additional cardiovascular risk factors, has a substantial impact on the outcome of the different association studies. With respect to the functional changes associated with the presence of the ACE D allele one can only speculate. The presence of the ACE D allele is associated with higher systemic ACE levels ${ }^{40}$, which may stimulate the local generation of angiotensin II ${ }^{41}$, which, in turn, can promote intima-media thickening. So far, however, no study has provided convincing evidence to support the assumption that more angiotensin II is formed locally.

The Apo $\mathrm{E}$ gene was one of the first of which polymorphisms associated with cardiovascular disease were studied thoroughly. This gene influences lipoprotein metabolism and the plasma concentration of total cholesterol, LDL cholesterol, apo $B$, and apo $E$, and it confers a risk for coronary heart disease. ${ }^{29}$ In our study, we did not find an association between the Apo E polymorphisms and carotid IMT. Several authors have studied the relation between IMT and Apo $E$ in the past. ${ }^{7,13,18,20,31}$ Among these, the recent study by Slooter et al. is the most powerful one. These authors found in the population-based Rotterdam study of 5401 elderly subjects (mean age 69 years) that carriers of the E2/E3 genotype had a slightly, but significantly, thinner IMT (mean difference $-0.02 \mathrm{~mm}$ ) than the most common E3/E3 group. Subjects with the Apo E4/E4 genotype had a bit more carotid atherosclerosis, which, however, was not statistically significant. So, while apo $\mathrm{E}$ helps to explain interpopulation differences of lipids and coronary heart disease, the findings of our study corroborate the general conclusions of the Rotterdam group that the Apo E4/ ${ }^{*}$ genotype is not an important risk factor for carotid IMT. In our study, we did not observe an inverse relation with the E3/E2 
combination, which may be due to the limited number of patients included in our study. However, if present, the small protective effects of this allele combination does not seem to justify population screening as a risk marker.

The hypothesis underlying this study was that interactions between candidate genes might influence carotid IMT by the growth stimulating effect of angiotensin II and the effects of (apo)lipoproteins on the vascular wall. More and more, the concept is emerging that genetic interactions between loci, rather than single genes, make up the genetic basis for cardiovascular disease. This concept was elegantly illustrated in the study of Balkestein et al. ${ }^{10}$ who showed an interaction between the ACE D allele, the $\alpha$-adducin 460Trp allele, and the aldosterone synthase $-344 \mathrm{~T}$ allele on the IMT of the femoral artery. There are no other studies that looked into the interaction of the ACE D allele and the Apo E4/* genotype. Although theoretically sound, we did not find an additive or synergistic effect for the E4 allele in the presence of the ACE D allele. Firstly, this may be due to the age of the population studied. The effect of genetic factors on cardiovascular disease may not be linear with age and different genes may act at different times during life. ${ }^{42}$ This could play a role in our study, since Slooter ef al. ${ }^{31}$ found a significant effect of the Apo $E$ genotype at relatively old age. Secondly, environmental factors may mask or enhance the effect of certain genes. This is probably not an important explanation for the lack of interaction in our study, since we assessed IMT in subjects with relatively mild hypertension and few risk factors for cardiovascular disease. Thirdly, genes may have a different impact on cardiovascular events, carotid, or femoral IMT. Although the latter possibility cannot be excluded, data from the literature do not suggest a differential effect of either the ACE D allele or the Apo E4 allele for several outcome parameters.

In accordance with our previous findings, the present study shows that a difference exists between IMT of the left and right carotid artery, with higher values on the left side. Also, cross-sectional area (a marker of vascular mass) of the IMT was larger on the left than on the right side. In most published studies IMT values are seldomly reported for the left and right carotid separately. However, in studies in which data are actually given for both sides, the IMT of the left common carotid tends, on average, to be larger than on the right ${ }^{11.43}$. Although the clinical significance of this asymmetry is not yet apparent, it has been shown recently that a thicker intima-media complex is associated with nonlacunar strokes ${ }^{44}$. Interestingly, the presence of an ACE D allele adds significantly, in an allele-dose dependent way, to this left-to-right difference. Unfortunately, it is not know whether subjects with the ACE I/D or D/D genotype are more prone to develop a stroke at the left hemisphere. Further prospective studies investigating this relation between IMT, side predilection for stroke, and genetic predisposition are ,therefore, necessary.

In conclusion, our study shows that the D allele of the ACE gene is associated in a gene-dose effect with increased common carotid IMT. Moreover, this effect was more pronounced at the left common carotid artery, and not affected by different Apo E alleles. This study further indicates that the Apo E gene is not an important marker for carotid atherosclerosis. 


\section{References}

1. Heiss G, Sharrett AR, Barnes R, Chambless LE, Szklo M, Alzola C. Carotid atherosclerosis meosured by B-mode ultrasound in populations: associations with cardiovascular risk factors in the ARIC study. Am J Epidemiol. 1991;134:250-256.

2. Salonen JT, Salonen R. Ultrasound B-mode imaging in observational studies of atherosclerofic progression. Circulation. 1993;87:1156-1165.

3. Folsom AR, Eckfeldt JH, Weitzman S, Mo J, Chambless LE, Barnes RW, Cram KB, Hutchinson RG. Relation of carotid artery wall thickness to diabetes mellitus, fosting glucose and insulin, body size, and physical activity. Atherosclerosis Risk in Communities (ARIC) Study Investigators. Stroke, 1994;25:66-73.

4. Gariepy J, Simon A, Massonneau M, Linhart A, Levenson J. Wall thickening of carotid and femoral arteries in male subjects with isolated hypercholesterolemio. PCVMETRA Group. Prevention Cordio-Vosculaire en Medecine du Travail. Atherosclerosis. 1995;113:141-151.

5. lannuzzi A, Wilcosky T, Mercuri M, Rubbo P, Bryan FA, Bond MG. Ultrasonogrophic correlates of carotid atherosclerosis in transient ischemic attack and stroke. Stroke. 1995;26:614-619.

6. Cuspidi C, Lonati L, Sampieri L, Pelizzoli S, Pontiggia G, Leonetti G, Zanchetti A. Left ventricular concentric remodelling and carotid structural changes in essential hypertension. J Hypertens. 1996;14:1441-1446.

7. Zannad F, Visvikis S, Gueguen R, Sass C, Chapet O, Herbeth B, Siest G. Genetics strongly determines the wall thickness of the left and right carotid arteries. Hum Genet. 1998;103:183-188.

8. Bots ML, Hoes AW, Hofman A, Witteman JC, Grobbee DE. Cross-sectionally assessed carotid intima-media thickness relates to long-term risk of stroke, coronary heart disease and death as estimated by available risk functions. J Intern Med. $1999 ; 245: 269-276$.

9. Held C, Hjemdahl P, Erikson SV, Bjorkander I, Forslund L, Rehnqvist N. Prognostic implications of intima-media thickness and plaques in the carotid and femoral arteries in patients with stable angina pectoris. Eur Heart J. 2001;22:62-72.

10. Balkestein EJ, Wang JG, H.A.J. S-B, Barlassina C, Bianchi G, Birkenhager WH, Brand E, den Hond E, Fagard R, Hermann S-M, van Boxtel LM, Staessen JA. Carotid and femoral intima-media thickness in relation to three candidate genes in a Caucasian population. J Hypertens. 2002;20:1551-1561.

11. Simon A, Gariepy J, Chironi G, Megnien JL, Levenson J. Intima-media thickness: a new tool for diagnosis and treatment of cardiovascular risk. J Hypertens. 2002;20:159-169.

12. Castellano M, Muiesan ML, Rizzoni D, Beschi M, Pasini G, Cinelli A, Salvetti M, Porteri $E$, Bettoni $G$, Kreutz $R$, et al. Angiotensin-converting enzyme $I / D$ polymorphism and arterial wall thickness in a general population. The Vobarno Study. Circulation. 1995;91:2721-2724. 
13. de Andrade M, Thandi I, Brown S, Gotto A, Patsch W, Boerwinkle E. Relationship of the apolipoprotein E polymorphism with carotid artery atherosclerosis. Am J Hum Genet. 1995;56:1379-1390.

14. Dessi-fulgheri P, Catalini R, Sarzani R, Sturbini S, Siragusa N, Guazzarotti F, Offidani M, Tamburrini P. Zingaretti $O$, Rappelli A. Angiotensin converting enzyme gene polymorphism and carotid atherosclerosis in a low-risk population. I Hypertens. 1995; 13:1593-1596.

15. Hosoi M, Nishizawa $Y$, Kogawa K, Kawagishi T, Konishi T, Maekawa K, Emoto $M$, Fukumoto S, Shioi A, Shoji T, Inaba M, Okuno Y, Morii H. Angiotensin-converting enzyme gene polymorphism is associated with carotid arterial wall thickness in noninsulin-dependent diabetic patients. Circulation. 1996;94:704-707.

16. Kauma H, Paivansalo M, Savolainen MJ, Rantala AO, Kiema TR, Lilja M, Reunanen A, Kesaniemi YA. Association between angiotensin converting enzyme gene polymorphism and carotid atherosclerosis. J Hypertens. 1996;14:1183-1187.

17. Kogawa K, Nishizawa $Y$, Hosoi M, Kawagishi T, Maekawa K, Shoii T, Okuno Y, Morii H. Effect of polymorphism of apolipoprotein $E$ and angiotensin-converting enzyme genes on arterial wall thickness. Diabetes. 1997;46:682-687.

18. Cattin L, Fisicaro M, Tonizzo M, Valenti M, Danek GM, Fonda M, Da Col PG, Casagrande S, Pincetri E, Bovenzi M, Baralle F. Polymorphism of the apolipoprotein $\mathrm{E}$ gene and early carotid atherosclerosis defined by ultrasonography in asymptomatic adults. Arterioscler Thromb Vasc Biol. 1997;17:91-94.

19. Girerd X, Hanon O, Mourad JJ, Boutouyrie P, Laurent S, Jeunemaitre X. Lack of association between renin-angiotensin system, gene polymorphisms, and wall thickness of the radial and carotid arteries. Hypertension. 1998;32:579-583.

20. Sass C, Zannad F, Herbeth B, Salah D, Chapet O, Siest G, Visvikis S. Apolipoprotein E4, lipoprotein lipase $C^{447}$ and angiotensin-I converting enzyme deletion alleles were not associated with increased wall thickness of carotid and femoral arteries in healthy subjects from the Stanislas cohort. Atherosclerosis. 1998;140:89-95.

21. Huang XH, Loimaala A, Nenonen A, Mercuri M, Vuori I, Pasanen M, Oja P, Bond G, Koivula T, Hiltunen TP, Nikkari T, Lehtimaki T. Relationship of angiotensinconverting enzyme gene polymorphism to carotid wall thickness in middle-aged men. J Mol Med. 1999;77:853-858.

22. Jeng JR. Carotid thickening, cardiac hypertrophy, and angiotensin converting enzyme gene polymorphism in patients with hypertension. Am J Hypertens. 2000;13:111-119.

23. Arnett DK, Borecki IB, Ludwig EH, Pankow JS, Myers R, Evans G, Folsom AR, Heiss $G$, Higgins $M$. Angiotensinogen and angiotensin converting enzyme genotypes and carotid atherosclerosis: the atherosclerosis risk in communities and the NHLBI family heort studies. Atherosclerosis. 1998;138:111-116.

24. Agerholm Larsen B, Nordestgaard BG, Tybjaerg Hansen A. ACE gene polymorphism in cardiovascular disease: meta-analyses of small and large studies in whites. Arterioscler Thromb Vasc Biol. 2000;20:484-492.

25. Wang JG, Staessen JA. Genetic polymorphisms in the renin-angiotensin system: relevance for susceptibility to cardiovascular disease. Eur I Pharmacol. $2001 ; 410: 289-302$. 
26. Smit M, de Krijff P, Rosseneu M, Bury J, Klasen E, Frants R, Havekes L. Apolipoprotein E polymorphism in The Netherlands and its effect on plasmo lipid and apolipoprotein levels. Hum Genet. 1988;80:287-292.

27. Davignon J, Gregg RE, Sing CF. Apolipoprotein E polymorphism and atherosclerosis. Arteriosclerosis. 1988;8:1-21.

28. Mazzone T. Apolipoprotein E secretion by macrophages: its potential physiological functions. Curr Opin Lipidol. 1996;7:303-307.

29. Eichner JN, Dunn ST, Perveen G, Thompson DM, Stewart KE, Stroehla BC. Apolipoprotein E polymorphism and cardiovascular disease: a HuGE review. Am J Epidemiol. 2002;155:487-495.

30. Ilveskoski E, Loimaala A, Mercuri MF, Lehtimaki T, Pasonen M, Nenonen A, Oja P, Bond MG, Koivula T, Karhunen PJ, Vuori I. Apolipoprotein E polymorphism and carotid artery intima-media thickness in a random sample of middle-aged men. Atherosclerosis. 2000;153:147-153.

31. Slooter A, Bots ML, Havekes LM, del Sol Al, Cruts M, Grobbee DE, Hofman A, Van Broeckhoven C, Witteman JC, van Duijn CM. Apolipoprotein E and carotid artery atherosclerosis: the Rotterdam study. Stroke. 2001;32:1947-1952.

32. Olmer M, Renucci JE, Planells R, Bouchouareb D, Purgus R. Preliminary evidence for a role of apolipoprotein E alleles in identifying haemodialysis patients at high vascular risk. Nephrol Dial Transplant. 1997;12:691-693.

33. Staessen JA, Wang JG, Brand E, Barlassina C, Birkenhager WH, Hermann S-M, al. e. Effects of three candidate genes on prevalence and incidence of hypertension in a Caucasian population. J Hypertens. 2001;19:1349-1358.

34. Laurent S. Genotype interactions and intima-media thickness. J Hypertens. 2002;20:1477-1478.

35. Mancia G, Parati G, Hennig M, al. e. Relation between blood pressure variability and carotid artery damage in hypertension: baseline data from the European Lacidipine Study on Atherosclerosis (ELSA). J Hypertens. 2001;19:1981-1989.

36. Boreas AM, Lodder J, Kessels F, al. e. Prognostic value of blood pressure in acute stroke. J Hum Hypertens. 2002;16:111-116.

37. Graf S, Gariepy J, Massonneau M, al. e. Experimental and clinical validation of arterial diameter waveform and intima media thickness obtained from B-mode ultrasound image processing. Ultrasound Med Biol. 1999;25:1353-1363.

38. Cheng S, Grow MA, Pallaud C, Klitz W, Erlich HA, Visvikis S, Chen JJ, Pullinger CR, Malloy MJ, Siest G, Kane JP. A multilocus genotyping assay for candidate markers of cardiovascular disease risk. Genome Res. 1999;9:936-949.

39. Hosmer DWJ, Lemeshow S. Interpretation of coefficients. In: Sons WJ, ed. Applied logistic regression. New York, USA; 1989.

40. Rigat B, Hubert C, Alhenc-Gelas F, Cambien F, Corvol P, Soubrier F. An insertion/deletion polymorphism in the angiotensin l-converting enzyme gene accounting for half the variance of serum enzyme levels. J Clin Invest. 1990;86:1343-1346.

41. Müller DN, Bohlender J, Hilgers KF, Dragun D, Costerousse O, Ménard J, Luft FC. Vascular angiotensin-converting enzyme expression regulates local angiotensin II. Hypertension. 1997;29[part 1]:98-104. 
72 Chapter 6

42. Snieder H, van Doornen U, Boomsma DI. The age dependency of gene expression for plasma lipids, lipoproteins, and apolipoproteins. Am J Hum Genet. 1997;60:638-650.

43. Lemne $C$, Jogestrand $T$, de Faire $U$. Carofid intima-media thickness and plaque in borderline hypertension. Stroke. 1995;26:34-39.

44. Cupini LM, Pasqualetti P, Diomedi M, Vernieri F, Silvestrini M, Rizzato B, Ferrante F, Bernardi G. Carofid artery intima-media thickness and lacunar versus nonlacunar infarcts. Stroke. 2002;33:689-694. 
Chapter 7

General discussion

Rodriguez Hernández SA, Kroon AA, de Leeuw PW 
74 Chopter 7 


\section{General discussion}

Under normal circumstances blood pressure varies considerably throughout the day. Perhaps the most striking and most consistent finding is the nocturnal decline in blood pressure. Although this has been amply demonstrated, the question has not been resolved whether this reflects a true circadian rhythm or that it is the result of variations in physical activity and rest. Whereas many studies tend to support the latter explanation, it is evident that lack of activity cannot be the sole explanation for a fall in pressure during sleep as the magnitude of the day-night difference in pressure becomes less and sometimes even disappears, for instance, in severe hypertension' or when renal function is impaired. ${ }^{2}$

It has been suggested that a blunted day-night rhythm could be due to volume retention during sleep. While this may be true for some patients, several arguments plea against this possibility as being very important. Indeed, the normal rhythm may be preserved in patients with primary aldosteronism and the loss of nocturnal hypotension in patients on hemodialysis does not seem to be related to fluid gain, but rather to the severity of hypertension. ${ }^{2}$ Furthermore, patients with essential hypertension in general do not display an exaggerated fall in sleeping pressures while they often do exhibit a reversal of the diurnal cycle in sodium excretion. ${ }^{3}$

From a hemodynamic point of view the fall in pressure during the night may be related to a decline in cardiac output or in peripheral vascular resistance or in both. Data on this issue are controversial. While some investigators observed a parallel decrease in arterial pressure and cardiac output ${ }^{4.5}$, others failed to find any consistent change in cardiac output. ${ }^{6}$ From personal experience, however, we know that it is extremely difficult, if not impossible, to obtain reliable estimates of cardiac output in sleeping subjects without causing some arousal. There is a need, therefore, for studies that will throw more light on the systemic hemodynamic alterations during sleep. Nevertheless, at the present time available data favour a reduction in vascular resistance rather than in cardiac output as the cause of the nocturnal blood pressure fall?

\section{Clinical significance of the diurnal blood pressure variations}

In recent years the interest in diurnal blood pressure variations has shifted from a pathophysiological paradigm into an epidemiological one. Nowadays, many researchers look upon the nocturnal blood pressure fall as a phenomenon with prognostic significance. Others emphasize that blood pressure surges during the day and the degree of the so-called blood pressure load determine the development of target organ damage. Despite these subtle differences in opinion, it has become clear that blood pressure variability has a much greater impact than originally thought. 
The most convincing way to show that blood pressure variability is important, is by demonstrating that cardiovascular prognosis in the long run is related to one or more components of the diurnal pressure profile. Interestingly, in this respect nighttime pressure seems to be a rather powerful predictor of cardiovascular prognosis. This has been demonstrated, for instance, in the Syst-Eur trial for an elderly population with isolated systolic hypertension. ${ }^{8}$ Others have pointed out that the magnitude of the nocturnal dipping of blood pressure is associated with target organ damage.' The latter investigators have divided their patients in socalled dippers and non-dippers based on the degree of the nocturnal blood pressure fall. Arbitrarily, a fall in pressure by more than $10 \%$ from daytime values was defined as dipping. However, while we do not want to underestimate the importance of the dipping phenomenon, there are problems with this definition. Except for uncertainty about the reproducibility of the degree of dipping, a dichotomous approach taking an arbitrary cut-off point is difficult to justify. Our policy, therefore, has become to treat the nocturnal pressure fall as a continuous rather than a dichotomous variable and to analyse all our data as such. If it is true that nocturnal pressure is even more important for prognosis than daytime pressure, one may even entertain the hypothesis that it is not noctural dipping, but rather daytime rising, which bears the prognostic information. This does not alter the described relationships between dipping and prognosis in numerical terms, but conceptually it may be a better approach of the truth.

\section{Hypertension and target organ damage}

During the natural history of essential hypertension progressive vascular disease develops which ultimately will cause target organ damage and overt clinical sequelae such as myocardial infarction, cerebrovascular accidents, peripheral arterial disease and loss of renal function. In epidemiological surveys and intervention trials these clinical complications are usually referred to as 'hard'endpoints. However, in this respect the term 'hard' refers more to the patients' experience than to the degree of accuracy that can be established with conventional diagnostic procedures. Indeed, with modern imaging techniques and refined laboratory methods it has become possible to measure objectively also a number of subclinical endpoints. For instance, renal damage can be defected by measuring micro-albuminuria and creatinine clearance, cardiac damage is demonstrable with echocardiographic methods as well as magnefic resonance imaging (MRI) procedures and cerebral damage can be detected by CT-scanning and MRI. While these abnormalities do not produce symptoms by themselves, they herald future complications of the hypertensive process and act as risk factors in their own right. In other words, the presence of left ventricular hypertrophy $(\mathrm{LVH})$, carotid artery disease or reduced renal function, to mention just a few, all predict the occurrence of further cardiovascular complications over and above the risk already brought about by the elevated blood pressure..$^{9.12}$ It is, therefore, no longer justified to dismiss the subclinical or intermediate endpoints as being of lesser importance. Even the widely held opinion that 
intermediate endpoints play no role in assessing the therapeutic value of antihypertensive drugs is a testimony of incogent neglect.

The cardiovascular endpoints of hypertension can be classified in various ways, namely by pathogenesis, by topography and by severity. All three aspects have been highlighted by McFate Smith in his report on the outcome of the USPHS trial. ${ }^{13}$ The USPHS investigators demonstrated a lot of acumen in categorizing the cardiovascular events met in their trial, both in terms of pathogenesis and of impact. Their pathogenesis-based subdivision of hypertensive organ damage into straightforward hypertensive events and those mediated through atherosclerosis (table 7.1) still makes sense today, even though such a strict distinction is no longer tenable in the light of more recently obtained evidence. Nevertheless, it is interesting that with modern antihypertensive treatment we have been able to substantially reduce cerebral infarction and (to a lesser extent) myocardial complications but we are not so good in reverting microcirculatory complications. As a matter of fact, congestive heart failure and renal insufficiency which are both related to microcirculatory disturbances, now are leading causes of hypertension-related morbidity and mortality.

Table 7.1. The two major substrates of hypertensive organ damage.

\section{Atherosclerotic}

Cerebral infarction

Myocardial infarction

Plaque formation in larger vessels

Hypertensive

Cerebral hemorrhage

Left ventricular hypertrophy and congestive heart failure

Aortic dissection

Encephalopathy or retinopathy, grade III or IV

Microcirculatory complications (e.g. renal insufficiency, malignant hypertension, lacunar cerebral infarction etcetera)

Adapted from ${ }^{13}$

The topical categorization of endpoints from the USPHS with some tiny modifications still serves as a template for the investigations which form the basis of the present thesis and which concentrate on four major targets of the hypertensive process: the heart, the brain, the kidneys and the larger vessels, in particular the carotid artery.

\section{The brain}

Hypertension is associated with an increased incidence of cerebral infarcts and hemorrhages. According to several inventories, atherothrombotic brain infarction is by far the commonest substrate of completed stroke, perhaps occurring with a frequency that is 20 times higher than that of intracerebral hemorrhage. However, besides territorial (or cortical) strokes, the hypertensive patient is prone to develop small vessel abnormalities leading to subcortical 
(lacunar) infarcts. In addition, it is increasingly being recognized that white matter lesions occur more frequently in a hypertensive population than in normotensive controls.

\section{The heart}

Long-standing hypertension is a major risk factor for the development of coronary complications and heart failure. Clinically, hypertensive heart disease manifests itself through the sequelae of cardiac hypertrophy and/or the symptoms and signs of coronary insufficiency. Both of these conditions may lead to ischemic events, arrhythmias and congestive heart failure. Hypertrophic responses of the heart do not only occur in response to pressure overload, but may be related to volume overload as well. In hypertension both pressure and volume effects seem to play a role.

Not uncommonly, hypertensive patients may have anginal complaints or other signs of myocardial ischemia in the face of angiographically normal coronary arteries. In these cases the imbalance between oxygen supply and demand is thought to be related to increased coronary resistance at the microvascular level. While the impediment to flow does not necessarily lead to symptoms at rest, it may do so after pacing or exercise.

\section{The kidneys}

In most recent hypertension trials, renal dysfunction appeared to be a rather uncommon endpoint. However, amongst others this may be due to suboptimal detection methods. Another explanation could be that a decline in renal function is a rather late complication, which can manifest itself only when the patient survives other circulatory threats on the heart and the brain. Anyway, in dialysis units hypertension has certainly become a more important cause of end-stage renal disease than intrinsic renal abnormalities.

\section{Large vessels}

The vascular complications associated with hypertension usually arise from atherosclerotic changes. Although the large arteries are not always regarded as end organs in their own right, they are particularly prone to injury in the presence of high pulsatile pressure and turbulence, and certain levels of shear stress. In this sense, they are involved in true end organ damage, as exemplified by such major catastrophes as dissecting aneurysm and occlusive peripheral artery disease. Before plaque formation and other frank atherosclerotic lesions become visible, one may see several other abnormalities such as reduced distensibility and compliance of the vascular wall, increased pulse wave velocity and thickening of the intima-media complex. However, even though the presence of these features correlates reasonably well with the risk of complications, it has not been established without doubt that these changes are true forerunners of atherosclerosis. 


\section{Pressure-related determinants of target organ damage in hypertension}

Epidemiological studies clearly show that a high blood pressure is not the only determinant of target organ damage, as hypercholesterolemia, diabetes, smoking and several other factors markedly enhance the risk of complications. Nevertheless, pressure remains one of the major risk factors. As we have seen above, though, the variations in pressure make it difficult to pinpoint one particular aspect of the elevated pressure as the culprit. In this regard, two lines of research are prevalent in the literature which both employ 24-hour ambulatory blood pressure monitoring (ABPM) as tool. One focuses on establishing a true diagnosis of hypertension and on verifying whether patients with high office pressures but low blood pressure values on ABPM behave differently as far as risk is concerned as compared to those with high values on both accounts. The other line of research tries to assess which component of the blood pressure pattern (daytime pressure, nighttime pressure, dipping, total variability etcetera) carries the best prognostic information. In this thesis we have followed both lines.

The issue that has arisen from the study of daily blood pressure profiles and that forms the core of Chapter 2 of this thesis is that of white coat hypertension. The identification of patients who show this phenomenon has led to the question whether this condition runs a benign course or not. Perloff and coworkers were among the first to show that patients with low ambulatory pressures relative to their clinic pressure have a lower risk. ${ }^{14.15}$ Later on, Verdecchia and colleagues reported a similar event rate per 100 patients-years for patients with white coat hypertension and normotensive persons, 0.49 and 0.47 , respectively. ${ }^{16}$ In contrast, the event rate in hypertensive dippers was 1.79 , and 4.99 per 100 patients-years in non-dippers. The investigators of the prospective populationbased Ohasama study reported that the ambulatory pressure was a better predictor of morbidity than screening pressure. ${ }^{17}$ Redon et al. examined subjects with refractory hypertension. ${ }^{18}$ They showed that subjects in the lowest tertile of ambulatory blood pressure had a significantly lower rate of morbidity over the next 4 years, despite similar clinic pressures. Investigators from the Northwick Park Hospital in London performed a 10 years follow-up study with ABPM. ${ }^{19}$ One of their findings was that only $11 \%$ of the patients with white coat hypertension had left ventricular hypertrophy, as compared with $38 \%$ of the patients with sustained hypertension. Similar differences were seen in carotid artery thickening. Taken all data together, the picture emerges of white coat hypertension being a relatively benign condition with a favourable course.

As far as target organ damage in patients with white coat hypertension is concerned data from the literature are conflicting but this may be related to insufficient control of 24-hour blood pressure, which was higher than in the control population in most studies. Therefore, we adopted a different policy in our work and matched patients with controls on the basis of the 24-hour blood pressure avarages. This analysis shows that white coat hypertension is, indeed, associated with a larger left ventricular mass. Although the difference did not extend into the pathological range, these results call at least for some caution. As the studied population was, on average, 40 years of age, it may be that with 
time LVH develops with the associated enhancement of risk. Obviously, only long-term follow-up data over periods of at least two decades will be able to provide the final verdict about the prognostic significance of white coat hypertension. For the time being, we believe that the condition is less innocent than has been assumed hitherto.

In chapter 3 and 4 of this thesis we have investigated the relationship between 24-hour blood pressure variability and target organ damage in heart, kidneys and brain respectively. With modern imaging techniques we were able to show a high percentage of white matter lesions (WML) in patients with essential hypertension who were temporarily off treatment. However, no clear relationship between the presence of these abnormalities and reduced nocturnal dipping was found. In fact, the reverse was true in that most lesions occurred in those patients with the greatest nocturnal fall in blood pressure. Based on these data it seems less likely that cerebral WML can be explained by the severity of hypertension alone. It is true that compared to patients without WML, those with this type of lesions have higher 24-hour systolic and diastolic blood pressure. ${ }^{20}$ Thus, an elevated blood pressure per se may be a risk factor for the lesions to appear but the severity of hypertension or, for that matter, the lack of nocturnal dipping (or daytime rising) does not have an additional effect. Maintained, or even exaggerated, falls in nocturnal blood pressure were also observed in patients with lacunar infarctions as recently defended by Boreas in her thesis (University of Maastricht, 2001). There are at least two possible explanations for these findings. The first is that the presence of WML or lacunar infarcts causes greater day-to-night variability of blood pressure but a second, and perhaps more intriguing explanation could be that patients with reduced nocturnal dipping are relatively protected against the deleterious effects of an elevated pressure. One could hypothesize that larger shift in pressure put a greater burden on autoregulatory systems in the brain, which may then decompensate at a faster pace than in patients in whom such shifts are smaller.

Contrary to the brain, the heart is quite sensitive to differences in 24-hour or nighttime pressure. As we showed in Chapter 3 left ventricular mass in treated patients is still higher as nighttime blood pressure is higher and this is true for patients with reduced dipping as well. Compared to well-controlled patients those who are inadequately treated fare even worse. Thus, our data suggest that cardiac damage closely follows the blood pressure burden. Surprisingly, though, this is not true for renal damage, measured by means of the creatinine clearance. In other words, in treated patients the kidney seems to be more resistant to the detrimental effects of hypertension or the reversal thereof by medication than the heart. Although our studies do not allow to construct a 'vulnerability' order, they suggest at least that such an order could be: heartkidney-brain (in descending order of sensitivity). The disparate effects of blood pressure on the various organs may be related to different pathophysiological mechanisms or, stated another way, to atherosclerotic or purely hypertensive complications. The latter (glomerulosclerosis, cerebral white matter matter lesions) seem to be more qualitative (i.e. less dependent upon the severity of hypertension), while the atherosclerotic lesions are more quantitative (i.e. very 
much dependent upon the height of pressure). This hypothesis could also explain why in the major hypertension trials the effect of treatment is much greater on (atherothrombotic) stroke and myocardial infarction than on microvascular complications, e.g. in the kidney.

Atherothrombotic cerebral infarction is related to carotid artery pathology and this is the reason why we also included studies on this part of the vasculature. Because an increase in the IMT of the common carotid artery may be a premonitory sign of carotid atherosclerosis, we evaluated whether IMT measurements could tell us anything about macrocirculatory cerebral complications of hypertension. Interestingly, we found a left-right difference in IMT (greater at left side) which has been noted before by others but which has not been elaborated on further. In our analysis, we were able to show also that atherothrombotic brain infarctions occur more frequently on the left side, thereby lending support for the hypothesis that both an increase in IMT and the occurrence of ischemic stroke are part of the same pathophysiological entity. Since lacunar infarcts show a symmetrical distribution, this again favours a different pathophysiology through changes in the local microcirculation.

Any review of atherosclerotic complications in hypertension would not be complete without paying at least some attention to genetic factors. Although various individual genes and genetic factors have been linked to the development of essential hypertension, a combination of multiple genes most likely contributes to the development of the disorder in a particular patient. It is extremely difficult, therefore, to accurately determine the relative contributions of each of these genes. Moreover, it is now well recognised that many common disorders, such as hypertension, arise from complex interactions between genes and environmental factors.

In intron 16 of chromosome 17 the presence (I) or absence (D) of a 287 base pair DNA fragment has been described. ${ }^{21}$ This polymorphism correlates with higher plasma ACE activity in subjects with one or two D-alleles. It has been shown that almost $50 \%$ of the interindividual variation in plasma ACE levels is determined by the ACE genotype. ${ }^{22}$ Numerous studies investigating the association between this polymorphism and blood pressure variation are conflicting. In meta-analyses, a correlation has been found with macro- and microvascular (renal) atherosclerotic complications but not with hypertension. ${ }^{23,24}$ A more recent meta-analysis ${ }^{25}$ has confirmed this observation, although, the association between the D-allele and ischemic heart disease could only be shown in smaller studies, using selected subgroups. Large studies failed to demonstrate this association, indicating the importance of the selection of subjects with the same genetic background. Whether there is a causal relationship between the presence of atherosclerotic disease and higher circulating ACE levels, or even more important, tissue ACE levels, is still a matter of debate. Whatever the background may be, our studies clearly show a relationship between the presence of the D-allele and a thicker intima-media complex, notably on the left side. In fact, the left-to-right difference is far greater in DD than in II individuals. This shows, as far as we know for the first time, a differential effect of genetics on different parts of the circulation. At the same 
time these data underscore our limited knowledge in this area. While we thought that the Apo E gene, which has been linked to atherosclerosis before, would show a relationship with IMT, this was not borne out by the facts. Future studies, therefore, have to focus upon other genes which may, either alone or in concert with the ACE gene, modify the IMT and, thereby, the risk of stroke.

\section{Limitations and perspectives}

Obviously, there are a number of limitations with respect to the studies that form part of this thesis. The patients were selected from a tertiary referral hospital and the results of the various studies, therefore, need not to be valid for all hypertensive subjects. Moreover, it is not possible anymore to study untreated patients over a prolonged period of time. Thus, studies had to be carried out in treated individuals or in patients who were temporarily off treatment. Whether medication could have influenced some of the results will remain unresolved. Finally, all measurements were obtained at only one point in time. This means that we are not well informed about the consistency of our data over time.

For the future, many additional studies are necessary which address exactly these points. Many more patients with different genetic background and degrees of atherosclerosis need to be studied. Other genetic markers have to be taken into account as well. We should also be prepared to go back to pathophysiology and decipher why purely hypertensive and atherosclerotic complications differ in their sensitivity to the effects of blood pressure. This may also pave the way for other treatment modalities and the development of new drugs.

Prospective therapeutic hypertension trials would benefit from better standardization of end organ damage criteria. This applies to clinical evaluation as well as ancillary techniques. In the hospital setting, numerous techniques are available for a rather accurate assessment of the nature of end organ damage encountered in the course of the hypertensive process but these need to be implemented at a larger scale. Finally, ambulatory blood pressure and assessment of nighttime blood pressure may become indispensible in the evaluation of the hypertensive patient. 


\section{References}

1. Verdecchia P, Schillaci G, Guerrieri M, Gatteschi C, Benemio G, Boldrini F, et al. Circadian blood pressure changes and left ventricular hypertrophy in essential hypertension. Circulation 1990;81:528-536.

2. Kooman JP, Glodziwa U, Bocker G, Wiinen JA, Bortel L, Luik AN, et ol. Blood pressure during the interdialytic period in haemodialysis patients: estimation of representative blood pressure values. Nephrol Dial Transplant 1992;7:917.923.

3. Dyer AR, Stamler R, Grimm R, Stamler J, Berman R, Gosch FC, et al. Do hypertensive patients have a different diurnal pattern of electrolyte excretion? Hypertension 1987;10:417-424.

4. Khatri IM, Freis ED. Hemodynamic changes during sleep in hypertensive patients. Circulation 1969;39:785-790.

5. Mori H. Circadian variation of hoemodynamics in patients with essential hypertension. J Hum Hypertens 1990;4:384-389.

6. Bristow JD, Honour AJ, Pickering TG, Sleight P. Cardiovascular and respiratory changes during sleep in normal and hypertensive subjects. Cardiovasc Res $1969 ; 3: 476-485$.

7. De Leeuw PW, Van Leeuwen SJ, Birkenhäger WH. Effect of sleep on blood pressure and its correlates. Clin Exp Hypertens 1985;A7:179-186.

8. Staessen JA, Thijs L, Fagard R, O'Brien ET, Clement D, De Leeuw PW, et al. Predicting cardiovascular risk using conventional vs ambulatory blood pressure in older patients with systolic hypertension. Systolic Hypertension in Europe Trial Investigators. JAMA 1999;282:539-546.

9. Levy D, Garrison RJ, Savage DD, Kannel WB, Castelli WP. Prognostic implications of echocardiographically, determined left ventricular mass in the Framingham Heart Study. N Engl J Med 1990;322:1561-1566.

10. Bikkina M, Levy D, Evans JC, Larson MG, Benjamin EJ, Wolf PA, et al. Left ventricular mass and risk of stroke in an elderly cohort. The Framingham Heart Study. JAMA 1994;272:33-36.

11. Ruilope LM, Salvetti A, Jamerson K, Hansson L, Warnold I, Wedel H, et al. Renal function and intensive lowering of blood pressure in hypertensive participants of the Hypertension Optimal Treatment (HOT) study. J Am Soc Nephrol 2001;12:218. 225.

12. De Leeuw PW, Thijs L, Birkenhager WH, Voyaki SM, Efstratopoulos AD, Fagard RH, et al. Prognostic significance of renal function in elderly patients with isolated systolic hypertension: results from the syst-eur trial. J Am Soc Nephrol 2002;13:2213-2222.

13. McFate Smith W. Treatment of mild hypertension: results of a ten-year intervention trial. US Public Health Service Hospitals Cooperative Group. Circulation Research 1977;40 (SI):198-1105.

14. Perloff D, Sokolow M, Cowan R. The prognostic value of ambulatory blood pressures. Jama 1983;249:2792-8. 
$84 \mid$ Chopter 7

15. Perloff D, Sokolow M, Cowan RM, Juster RP. Prognostic value of ambulatory blood pressure measurements: further analyses. J Hypertens 1989;7:S3-10.

16. Verdecchia P, Schillaci G, Borgioni C, Ciucci A, Porcellati C. Prognostic significance of the white coat effect. Hypertension 1997;29:1218-1224.

17. Ohkubo T, Imai Y, Tsuii I, Nagai K, Watanabe N, Minami N, et al. Prediction of mortality by ambulatory blood pressure monitoring versus screening blood pressure measurements: a pilot study in Ohasama. J Hypertens 1997;15:357-364.

18. Redon J, Campos C, Narciso ML, Rodicio JL, Pascual JM, Ruilope LM. Prognostic value of ambulatory blood pressure monitoring in refractory hypertension: a prospective study. Hypertension 1998;31:712-18.

19. Khattar RS, Senior R, Lahiri A. Cardiovascular outcome in white-coat versus sustained mild hypertension: a 10-year follow-up study. Circulation 1998;98:18921897.

20. Sierra C, de La Sierra A, Mercader J, Gomez-Angelats E, Urbano-Marquez A, Coca A. Silent cerebral white motter lesions in middle-aged essential hypertensive patients. J Hypertens 2002;20:519-524.

21. Tiret L, Rigat B, Visvikis S, Breda C, Corvol P, Cambien F, ef al. Evidence, from combined segregation and linkage analysis, that a variant of the angiotensin 1converting enzyme (ACE) gene controls plasma ACE levels. Am J Hum Genet 1992; 51:197-205.

22. Cambien F, Alhenc-Gelas F, Herbeth B, Andre JL, Rakotovoo R, Gonzales MF, et al. Familial resemblance of plasma angiotensin-converting enzyme level: the Nancy Study. Am J Hum Genet 1988;43:774-780.

23. Staessen JA, Wang JG, Ginocchio G, Petrov V, Saavedra AP, Soubrier F, et al. The deletion/insertion polymorphism of the angiotensin converting enzyme gene and cardiovascular-renal risk. J Hypertens 1997;15:1579-592.

24. Agerholm-Larsen B, Nordestgaard BG, Tybjaerg-Hansen A. ACE gene polymorphism in cardiovascular disease: meta-analyses of small and large studies in whites. Arterioscler Thromb Vasc Biol 2000;20:484-492.

25. Keavney B, McKenzie C, Parish S, Palmer A, Clark S, Youngman L, et al. Large-scale test of hypothesised associations between the angiotensin- converting-enzyme insertion/deletion polymorphism and myocordial infarction in about 5000 cases and 6000 controls. International Studies of Infarct Survival (ISIS) Collaborators. Lancet 2000;355:434-442. 
Chapter 8

Summary 
86 Chapter 8 


\section{Summary}

This thesis is dedicated to the problem of target organ damage (TOD) in patients with essential hypertension. High blood pressure is one of the, if not the most important risk factor for cardiovascular complications such as myocardial infarction, cerebrovascular accident, and peripheral vascular disease. The kidney plays a special role in that this organ may be both culprit and victim of the hypertensive process. TOD is generally considered an intermediate endpoint, the presence of which accelerates the risk of overt cardiovascular events. The purpose of the studies described in this thesis was to shed more light on the relationship between blood pressure variability and TOD. The first aspect of this relationship concerns the problem of white coat hypertension (WCH) and is covered in Chapter 2. The question raised in that chapter was whether WCH should be considered as a variant of 'true' hypertension with its TOD or as a rather innocent phenomenon without TOD. The results of our retrospective analysis clearly show that WCH is associated with a larger left ventricular mass than normotensives and that these changes are independent of blood pressure load as measured by 24 -hour recordings. Thus, WCH does not appear to be an entirely benign condition, but larger prospective follow-up studies are necessary to determine long-term risk of morbidity and mortality associated with this abnormality.

In chapter 3 certain target organ changes (in heart and kidney) are related to blood pressure variability. Because a lot of data already exist with respect to such changes in untreated patients, the data in chapter 3 focus on treated patients. This was primarily driven by the question whether long-term treatment would be able to reduce TOD. Based on the 24-hour blood pressure profile we divided our patients into three groups of adequately treated, inadequately treated and borderline treated blood pressure. TOD was measured by echocardiography (heart) and serum creatinine, creatinine clearance and microalbuminuria (kidney). Interestingly, the results of our analysis show different patterns for the heart and the kidney. When related to the severity of hypertension, in this case expressed as the degree of treatment adequacy, left ventricular mass is quite sensitive to the prevailing ambulatory blood pressure level while renal function is not. In other words, patients who are inadequately treated have higher left ventricular mass but similar renal function as those who are adequately treated. Apparently, renal damage is less easy to revert than cardiac damage. The data, however, also show that reduced nocturnal dipping was associated with both a higher cardiac mass and impaired renal function. This means that a higher nocturnal pressure or, stated differently, a smaller dayto-night difference in pressure, causes greater damage in both target organs. As shown in Chapter 4, the latter phenomenon is quite opposite to what occurs in the brain. Indeed, when untreated patients were investigated for the presence of so-called white matter lesions, an abnormality supposedly related to 
hypertension and aging, these lesions appeared to occur less often in the presence of a blunted day-night rhythm. We speculated that smaller swings in blood pressure may protect the brain from microvascular damage in this respect. Thus, the results from chapters 2 to 4 illustrate the heterogeneous response of target organs to the hypertensive process. Certainly, it is not justified anymore to assume a simple pressure-damage relationship in hypertension.

Whereas in Chapter 4 attention was paid to a microcirculatory complication, in Chapter 5 a macrocirculatory effect is discussed, namely changes in carotid artery wall. Although we did not consider plaque formation, we looked at the intima-media thickness (IMT) which probably predicts future vascular events. Interestingly, we found a left-to-right difference with higher values occurring at the left side. Because we speculated that this could mean that atherothrombotic cerebrovascular accidents would also occur more frequently in the left hemisphere we explored the database of the Maastricht Stroke Registry which contains the data of all stroke patients who have been admitted to our hospital since 1988. Our analysis, indeed, indicated that atherothrombotic cerebral infarcts are significantly more often localized in the left hemisphere whereas lacunar infarcts show a symmetrical distribution. This underscores, once again, the impact of different pathological and pathophysiological processes: even distribution of microvascular complications (white matter lesions) but asymmetric distribution of macrocirculatory complications.

In Chapter 6 the side preference of carotid artery wall abnormalities is taken a step further by relating these to certain genetic polymorphisms. While we had expected the changes in IMT to be related to the Apo E gene (which has been linked to atherosclerosis), we did not find evidence for such a relationship. On the contrary, the ACE gene did have an effect. The presence of one or two D. alleles of this gene significantly increased the IMT and the left-to-right difference in IMT. The ACE gene has also been implicated in the pathogenesis of atherosclerosis and our data lend further support to that hypothesis.

Finally, in Chapter 7 the results of the various studies are discussed in the light of data from the literature. We propose to make a clear distinction between microcirculatory and macrocirculatory complications and to consider the possibility that the various components of the 24-hour blood pressure profile may have a different impact on the various target organs of the hypertensive process. 
Chapter 9

Samenvatting 
90 Chapter 9 


\section{Samenvatting}

Dit proefschrift is gewijd aan het probleem van eindorgaanschade bii patiënten met essentiële hypertensie. Hoge bloeddruk is een van de, zo niet de, belangrijkste risicofactor voor cardiovasculaire complicaties zoals myocard infarct, cerebrovasculaire accidenten en perifeer vaatlijden. De nieren spelen een belangrijke rol bij het ontstaan en bij de gevolgen van hypertensie. Eindorgaanschade wordt algemeen beschouwd als een tussenstadium. Het is enerzijds een viting van onvoldoende gereguleerde hypertensie, anderzijds bepaalt het de verdere cardiovasculaire prognose. Het doel van de studies in dit proefschrift is om meer helderheid te verkriigen over de relatie fussen bloeddrukvariabiliteit en eindorgaanschade. Het eerste aspect van bloeddrukvariabiliteit heeft betrekking op het probleem van "witte jas hypertensie". Dit wordt beschreven in hoofdstuk 2. De vraag die we probeerden te beantwoorden in dit hoofdstuk was of witte jas hypertensie als een variant van "echte" hypertensie met eventueel eindorgaanschade moet worden beschouwd of dat dit toch gezien moet worden als een onschuldig fenomeen zonder eindorgaanschade. De resultaten van onze refrospectieve analyses tonen duidelijk, dat witte jas hypertensie is geassocieerd met een toegenomen linker ventrikelmassa en dat deze verandering onafhankelijk is van de mate van bloedrukbelasting gemeten met behulp van een 24-uurs ambulante bloeddrukmeter. Kortom witte jas hypertensie lijkt niet een volledig onschuldig fenomeen te zijn. Grotere prospectieve studies zijn evenwel nodig om de lange termijn risico's ten aanzien van morbiditeit en mortaliteit vast te leggen.

In hoofdstuk 3 is de orgaanschade in hart en nieren gerelateerd aan de variabiliteit van de bloeddruk. Omdat er in dit opzicht genoeg gegevens bestaan bij onbehandelde hypertensieven, hebben wij in deze studie behandelde hypertensieven onderzocht. De vraagstelling hierbii was of lange termiin behandeling met bloeddrukverlagende medicamenten in staat zouden zijn om eindorgaanschade te doen verminderen. Op basis van 24-uurs bloeddrukregistraties werden de patiënten in drie groepen onderverdeeld: adequaat behandeld, inadequaat behandeld en borderline behandeld. Eindorgaanschade werd gemeten met behulp van echografie van het hart en de bepaling van het serum-kreatinine, de berekening van de kreatinineklaring en het bepalen van microalbuminurie. Uit de analyses kwam naar voren dat het effect van bloeddrukverlaging verschillend was voor het hart en de nieren. De ernst van hypertensie, in dit geval uitgedrukt in de mate waarin de bloeddruk onder een bepaalde streefwaarde kwam, was sterk bepalend voor de ernst van linker ventrikel hypertrofie terwijl dat voor de nierfunctie uitgedrukt in kreatinineklaring geen gevolgen had. Met andere woorden, patiënten die adequaat behandeld zijn hebben een lagere linker ventrikel massa, maar een even verslechterde nierfuncties als de adequaat behandelden. Schijnbaar is nierschade minder makkeliik terug te draaien dan hartschade. Niet 
tegenstaande dit gegeven vonden we wel een omgekeerde verband tussen de mate van nachteliike bloeddrukdaling en schade, zowel voor linker ventrikel hypertrofie als voor nierfunctie. Dit betekent dat hogere nachteliike drukken, of anders verwoord, kleinere dag-nacht verschillen in bloeddruk, grotere schade aan beide doelorganen aanrichten. Zoals beschreven in hoofdstuk 4 , is het bovenbeschreven fenomeen geheel omgekeerd voor de schade van hoge bloeddruk in de hersenen. Sterker nog, onbehandelde patiënten met hypertensie hebben minder witte stof schade, een afwijking die werd gemeten met MRI, dan bij een afwezige nachtelijke bloeddruk daling. Op grond hiervan veronderstellen wii dat kleinere veranderingen in bloeddruk tussen dag en nacht beschermend zouden kunnen werken voor de hersenen. De resultaten van hoofdstuk 3 en 4 illustreren de heterogene respons van eindorganen op het hypertensieve proces. Hier volgt ongetwijfeld uit dat het niet meer vanzelfsprekend is te veronderstellen dat er een simpele druk-schade relatie bestaat bij hypertensie.

Terwijl in hoofdstuk 3 en 4 aandacht is besteed aan de microcirculatoire complicaties van hoge bloedruk, worden in hoofdstuk 5 de macrocirculatoire gevolgen nader belicht, in het bijzonder de dikte van de binnenbekleding van de vaatwand van de halsslagader (het zogenaamde intima-media complex). De dikte van het intima media complex, gemeten met echografie, hangt samen met toekomstige vasculaire complicaties: hoe dikker dit complex, hoe meer kans op gegeneraliseerde atherosclerotische vaatschade. Interessant was onze bevinding van een links-rechts verschil: de linker halsslagader was meestal dikker dan de rechter. Om te onderzoeken of deze toegenomen vaatschade samenhangt met atherotrombotische herseninfarcten aan de linkerkant, hebben wii gebruikt gemaakt van de Maastricht Stroke Registry. Dit is een bestand dat gegevens bevat van alle patiënten die sinds 1988 onderzocht zijn in ons ziekenhuis wegens een herseninfarct. Onze analyses toonden inderdaad aan dat atherotrombotische infarcten vaker voorkomen in de linker hemisfeer, terwiil lacunaire infacten een gelijke verdeling tussen links en rechts tonen. Dit benadrukt nogmaals het belang van verschillende pathologische en pathofysiologische processen die het gevolg zijn van hoge bloeddruk: gelijke verdeling van microvasulaire complicaties (witte stof laesies), maar een ongeliike verdeling van macrocirculatoire complicaties.

In hoofdstuk 6 zijn de veranderingen in het intima-media complex verder geanalyseerd door deze te relateren aan genetische polymorfismen. Terwij wij gedacht hadden een relatie te vinden tussen intima-media dikte en het Apo $E$ gen (een gen dat is gerelateerd aan atherosclerose), vonden wij een associatie met het ACE insertie/deletie polymorphisme. Bij aanwezigheid van een of twee D-allelen van het ACE-gen vonden wij een significante toename van de intimamedia dikte en met name aan de linker kant. Deze bevindingen ondersteunen de reeds eerder geformuleerde hypothese dat er een relatie bestaat tussen het ACE-gen en de ontwikkeling van atherosclerose.

Tot slot hebben wij in hoofdstuk 7 de resultaten van de verschillende onderzoeken vit dit proefschrift becommentarieerd tegen het licht van gegevens vit de literatuur. Wij suggereren dat het belangrijk is een duidelijk onderscheid te maken tussen microcirculatoire en macrocirculatoire complicaties van hoge 
bloeddruk en om de mogelijkheid in acht te nemen dat de verschillende componenten van de 24-uurs bloeddrukregistratie verschillende aangrijpingspunten kunnen hebben op de verschillende doelorganen die betrokken zijn in het hypertensieve proces. 
Dankwoord 


\section{Dankwoord}

Alle beschreven onderzoeken in dit proefschrift zouden niet mogelijk geweest zijn zonder medewerking en belangeloze deelname van proefpersonen. Aan hun wil ik op de eerste plaats mijn woorden van dank betuigen.

Naast de mensen op wie dit proefschrift gebaseerd is, zijn er vele anderen die op basis van hun deskundigheid een bijdrage hebben geleverd aan het tot stand komen van dit proefschrift. Als eerste wil ik hierin mijn promotor Prof. de Leeuw bedanken. Beste Prof misschien weet $u$ het niet maar $u$ bent degene die mij het langst kent. Begin 1993 was onze eerste ontmoeting waarin ik u mijn wens kenbaar maakte om "iets" te doen binnen de Interne Geneeskunde. Alleen wisten we toen niet dat het zou vitmonden in een promotie. $U$ heeft mij weten te inspireren voor het wetenschapelijk onderzoek, alsmede nieuwsgierig gemaakt voor de Vasculaire Geneeskunde. Uw bijna obsessieve geloof in een goede afloop was een mooi contrast ten opzicht van mijn vaak wat sombere instelling. Ik voel me vereerd $u$ als leermeester, voorheen voor wetenschappelijk onderzoek nu voor het klinisch werk te mogen hebben. Uw altiij zo vriendelijke en gastvrije houding zijn sterke kanten die ik als prettig heb weten te ervaren. Ten tweede wil ik mijn co-promotor Dr. Kroon bedanken. Beste Bram, naast jouw kennis en begeleiding heb ik jouw betrokkenheid bij de onderzoeker als persoon als prettig ervaren. Je wist het "vliegwiel" bij mij draaiende te houden. $\mathrm{lk} \mathrm{zal}$ in jouw lange termijn geheugen ingeprent worden: elke (co)promotor weet immers nog wie zijn eerste promovendus is. Mijn tweede co-promotor is Dr. van Boxtel. Beste Martin, ik ben dankbaar dat je mijn epidemiologische kennis, het vaste onderdeel van elk wetenschappelijk onderzoek, hebt kunnen vormen. Jij wist de scheve data te normaliseren en deze kritisch te analyseren. Jouw bijdrage aan de analyses van de witte stofschade mag niet ongenoemd blijven. Ook bii jou zal ik een plek in je geheugen hebben, ik hoop ver van mogelijke witte stof aandoeningen.

Monique Bessems wil ik bedanken voor haar logistieke steun en het afnemen van de neuropsychologische tests bij de vrijwilligers. Jij bent de bindende factor geweest tussen neuropsychologie en medische aspecten van het onderzoek die in dit proefschrift verder niet worden beschreven.

Mijn paranymfen moesten belangrijke personen zijn die direct of indirect betrokken waren bij het tot stand komen van dit proefschrift, maar door omstandigheden niet als auteurs genoemd worden. Mijn eerste paranymfe is $\mathrm{Dr}$. M. Krekels. Beste Marielle, een groot deel van wat ik nu weet over computerprogramma's en het maken van presentatie posters heb ik aan jou te danken. Jij hebt aan de wieg van mijn wetenschappelijke carrière gestaan. Jouw geduld was een noodzaak voor het in stand houden van mijn wetenschappelijke aspiraties. Mijn tweede paranymf is Drs. H. Beckers. Beste Leon, aan jou heb ik mijn zachte " $g$ " te danken. Jij hebt mij erop gewezen dat voetgangers in Nederland voorrang hebben en dat fietsers ook meedoen aan het verkeer. 
Onze studieavonden hebben we inmiddels verruild voor filosofische gesprekken over het doel van ons bestaan.

Onderzoeken vinden vaak plaats in laboratoria, ook hier is dat het geval geweest. Allereerst wil ik iedereen die betrokken is bii het Circulatie laboratorium van het Academisch ziekenhuis Maastricht bedanken voor hun medewerking en tolerantie ten aanzien van mijn aanwezigheid op hun werkvloer. Het laboratorium voor klinische neurofysiologie, in het bijzonder Drs. W. Mess, wil ik bedanken voor het vitvoeren van de intima-media metingen bij de vrijwilligers. Het CATG laboratorium bemand door Dr. P. Schiffers en Michael Geurts wil ik bedanken voor de genotypering van de bloedmonsters. Nico Rozendaal (Neuropsychologie) en Drs. Wilko Spiering (Interne Geneeskunde) zijn belangrijk geweest voor hun bijstand bij computer problemen alsmede het ontwikkelen van programma's voor het invoeren van de data. Beste Wilko, ook bedankt voor het bewaken van het project tijdens mijn afwezigheid. Dr. P. Hofman, radioloog, wil ik bedanken voor het kritisch beoordelen alsmede meten van de witte stof schade op de MRI's van de hersenen.

I would like to thanks Professor O'Brien and all his staff members from the Blood Pressure Unit, Beaumont Hospital Dublin-Ireland for their help and guidance in all matters concerning ambulatory blood pressure monitoring.

Beste Tiny, zonder jou zou dit boek niet in drukvorm verschenen zijn. Jij bent en blijtt een belangrijk persoon die elke promovendi nodig heeft bij zijn/haar promotie.

Mijn nieuwe collegae wil ik bedanken voor het accepteren van mijn klinische onbenulligheid na enkele, "slechts" digitale jaren. Aan jullie is het te danken dat ik met vertrouwen mijn nieuwe rol kan aannemen.

Mijn moeder wil ik bedanken voor haar steun en onvoorwaardelijke liefde die grote afstanden wisten te overbruggen.

Lieve Helen, deze fase in mijn leven is niet denkbaar zonder jou. Er zullen meerdere volgen, alleen met jouw steun en vertrouwen zullen zij makkelijk te overwinnen zijn. 
Curriculum vitae 


\section{Curriculum vitae}

Sergio Alejandro Rodriguez Hernóndez werd geboren op 19 maart 1971 te Bogotá Colombia. Op Curaçao, Nederlandse Antillen, behoalde hij in 1987 zijn MAVO diploma oan het Amodor Nita College. In 1989 volgden de HAVO en in 1991 het WWO diploma aan het Peter Stuyvesant Lyceum te Curaçao. Aansluitend begon hii zijn studie Geneeskunde aan de Rijksuniversiteit Limburg. $\mathrm{Hij}$ volgde een aantal co-schappen in het buitenland; Chirurgie (Vall d'Hebron Hospital Departamento de Cirugia General Barcelona-Spanje; Prof. dr. G. Kootstra en Prof. dr. M. Almengol), Oogheelkunde (Istituto di Clinica Oculistica dell' Università di Firenze, Firenze-ltalia; Mw. Dr. M. Beintema en Prof. dr. R. Frosini), Gynaecologie \& Obstetrie (Sint Elizabeth Hospital Willemstad. Curaçao Nederlandse Antillen; Dr. G. Dunselman en drs. F. Capello) en Kindergenees. kunde (Hospital Clinico San Cecilio Granada-Spanje; Dr. W. Gerver en Prof.dr. G. Galdó Muñoz). Van 1994 tot en met 1997 was hii student-assistent bii de afdeling Interne Geneeskunde (Prof. dr. P.W. de Leeuw en Dr. M.M.E. Krekels) van het academisch ziekenhuis Maastricht. In 1996 ontving hii de studentenprijs binnen het Dr. Dekker programma van de Nederlandse Hartstichting. Dit maakte het mogelijk om gedurende 3 maanden te werken op de afdeling Cardiologie (Blood Pressure Unit) van het Beaumont Hospital te Dublin-lerland. Hier werd de basis gelegd voor twee artikelen uit dit proefshrift (Prof. dr. E. O'Brien). In 1999 werd het artsexamen behaald aan de Universiteit Maastricht, waarna hii als AGNIO werkzaam was in het St. Maartens Gasthuis te Venlo, afdeling Interne Geneeskunde (Dr. A. Luik). Dit werd onderbroken om zijn onderzoek te kunnen afmaken. De overige studies die in dit proefschrift beschreven zijn werden vitgevoerd tijdens een aanstelling als arts-onderzoeker bii de vakgroep Psychiatrie en Neuropsychologie (Prof. dr. J. Jolles en Dr. M. van Boxtel) in samenwerking met de vakgroep Interne Geneeskunde (Prof. dr. P. W. de Leeuw en Dr. A.A. Kroon) in de periode 2000-2002. Op dit moment is hii AGNIO Interne Geneeskunde in het academisch ziekenhuis Maastricht. 
